\title{
Plant Based Pesticides: Green Environment with Special Reference to Silk Worms
}

\author{
Dipsikha Bora, Bulbuli Khanikor and Hiren Gogoi
}

Additional information is available at the end of the chapter

http://dx.doi.org/10.5772/47832

\section{Introduction}

Pesticides once having entry to an environment either get into the complex web of life through food chain or different components of the environment through physical passages like drifting by air and aquatic runways. Such facts were meticulously described by Rachel Carson [1] in her book 'Silent spring' where she advocated for choosing either the chemical control or biological control to avoid creation of endless problems to mankind owing to pesticide use. Looking back at the history of tremendous potentiality of synthetic chemicals to manage insect pests followed by subsequent cases of failure of chemical control due to development of insect resistance and pest resurgence, here we intend to cite examples of selective toxicity of insecticides and reiterate its importance in management of insect pests. Pesticidal pollution is a global problem. Use of synthetic insecticides to control pest around the world has resulted in disturbances of the environment, secondary pest resurgence, pest resistance to pesticides, lethal effects to non-target organisms as well as direct toxicity to users. It has been reported that about 2.5 million tons of pesticides are used on crops each year and the worldwide damage caused by pesticides reaches $\$ 100$ billion annually. The reason behind this amount of cost is the high toxicity and non biodegradable properties of pesticides and the residues in soil, water resources and crops that affect public health [2]. Hence search for the environment friendly, highly selective, newer biodegradable pesticides for pest management programme has been advocated to be essential for last several decades.

South East Asian countries are the hubs for production of raw silks produced by sericigenous insects namely Bombyx mori (mulberry silk worm), Antheraea assama (Muga silk worm), Antheraea mylitta (Tasar silk worm) and Philosamia ricini (Eri silk worm). India holds second position in world's raw silk production and contributes to $13.45 \%$ of the total production [3].Yet the production is not sufficient even to meet the domestic demand of the 
raw silk. One of the major constraint in silk production is the susceptibility of the silkworms to attack of different pests, parasitoids, predators and pathogens. Even mulberry silkworms which can be cultured in indoor condition are not free from such constraints. In addition, their host plants are also susceptible to the attack by herbivorous pests (insects, mites) and various pathogens (Nematodes, bacteria, fungus and virus) [4,5]. Growth and development of silkworm to a great extent depend on quality and quantity of food consumed and utilized [6]. In such situations, usually farmers take shelter of spurious chemicals for controlling the pest population unless they are well versed with efficacy of pesticides and their hazardous effects. Application of insecticide in sericulture field is not at all advisable as the leaves of host plants are directly consumed by the silk worms and silk worms become affected either through consumption of contaminated food or contact toxicity of the insecticides. Bombyx mori are highly susceptible to insecticides and in China its production is reported to be decreasing by almost $30 \%$ per annum because of insecticidal poisoning [7]. Fenvalerate-20EC (Sumicidine-20EC), one of the commonly used pyrethroid, reduced the rate of feeding, assimilation and efficiencies of conversion of ingested and digested food into body substance in late instar larvae of Bombyx mori [8]. Hexachlorocyclohexane, an organochloride insecticide was reported to cause decrease in fibroin content, pupal and shell weight, adult emergence percentage, fecundity as well as deterioration in quality and quantity of silk thread in B. mori [9]. About 50\% of normal water intake of eri silkworm (Philosamia ricini) was reported to decrease after feeding with leaves of Ricinus communis treated with permethrin, a pyrethroid insecticide which might have resulted due to repellency or disruption of feeding physiology [10]. The chemicals used if are phytotoxic reduce the nutritive quality of the leaves. It is globally accepted that complete elimination of pesticide drift is impossible. More often sericulture fields are contaminated by insecticides sprayed into other crop systems in the neighbouring areas. For instance many of the nonmulberry- sericulture fields in Brahmaputra Valley of Assam are situated mostly in close vicinity of stretches of crop fields like paddy and tea. Thus those sericulture fields cannot be expected to be spared of indirect contamination caused by widespread use of pesticides in paddy fields and tea gardens that warns precautionary measures (Plates 1).

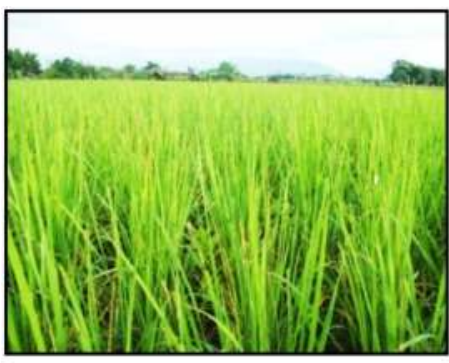

Paddy field

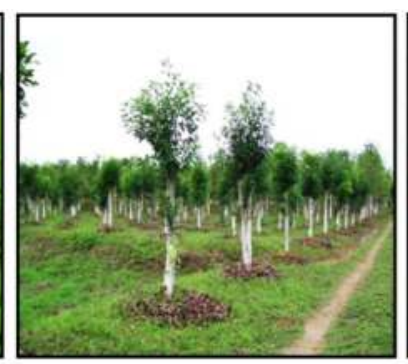

Sericulture field

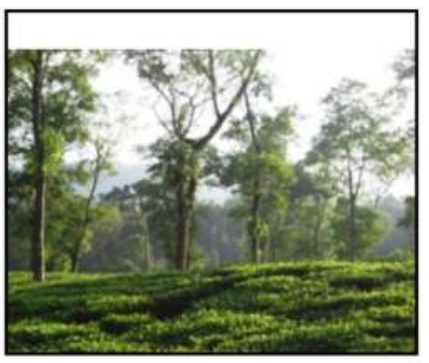

Tea garden

Plate 1. Components of Seri-ecosystem in Assam 


\section{Pesticides in environment}

Introduction of pesticides into a crop system subjects it into a variety of physico-chemical and biological processes which determine the persistence, fate and the ultimate degradation product. Many workers have shown that only a portion of pesticides sprayed onto crops reach their targets, the rest enter the atmosphere by spray drift, volatilization from soil or water, surface runoff, biotransformation by microorganisms, plants, animals, biomagnification through food chain and photodecomposition [11]. One of the major environmental aspect is the effect of sunlight that may lead to various photoprocesses and to photoproducts which are mostly different from parent pesticides in the environmental properties and toxicological significance. The quantum of light energy emitted from the radiation is absorbed by pesticides in environment and this raises the energy state of the molecule, causes excitation of electrons leading to formation or disruption of chemical bonds. Photolysis of pesticides have been studied in water, soil and plant surface. Various sensitizers present in environment such as riboflavin, humic substance etc. absorb light energy and serve as donor of energy to pesticide acceptor and bring about photodecomposition of pesticides. Most organophosphates whose photochemistry have been studied are phosphorothioate and phosphorodithiotate compounds. Although not highly susceptible to photodegradation by UV light, malathion degrades to different photoproducts such as malaoxon, malathion diacid, o,o-dimethyl phosphorodithioic acid, o,o-dimethyl phosphorothioic acid and phosphoric acid [12,13].Some of the compounds viz. malaoxon are more toxic than the parent compound. Insecticides aimed against pest population may enter non-target arena through spillage at sublethal level but even these sublethal dosages may exert considerable damage on behaviour and activity of non-target population [14]. Pesticidal effect of insecticides at sublethal dosages may have long term effect and they may be expressed at a later part of the insect's life [15,6].Continuous exposure to sublethal dosages on the environment may on the otherhand help a pest to develop resistance mechanism against the toxic compound. Troitskaya and Chichigina [16] showed that combined use of bacterial and chemical insecticides in silk-producing areas possess a real danger to Bombyx mori.

2.1. A study was carried out to evaluate the susceptibility of the silkworm, Antheraea assama to sublethal dosages of organophosphorous chemicals, malathion and phosphamidon in terms of certain developmental and biochemical parameters. The insecticides were sprayed to leaves at sublethal concentrations based on LD50 values determined earlier and allowed the fifth instar larvae to feed on them in $12 \mathrm{D}$ : 12L photoperiodic condition. The parameters considered were mean larval growth rate, food consumption and utilization computed by the method of Waldbauer (17). In case of malathion treatment although at the lowest dose applied the mean daily consumption, utilization and mean larval weight did not vary significantly they decreased at higher dosages. The correlation coefficient between the mean daily consumption and utilization of food and concentrations of insecticide was -0.826 and 0.812 respectively. This represented a feeding deterrent effect of malathion and its ability to 
interfere with digestive physiology. Accordingly the growth rate and in later part of developmental period, the percentage of pupation and adult emergence decreased even at lower concentration. In case of treatment with phosphamidon, the daily food consumption and utilization decreased but they did not vary at the highest dose. The correlation coefficient between the mean daily consumption and concentrations of phosphamidon were +0.539 which might indicate probable absence of feeding deterrence ability in phosphamidon. The growth rate decreased, but the mean larval weight increased with increase of concentration and the correlation coefficient between larval weight and concentrations of phosphamidon was +0.930 . Although variations were observed in effect of different concentration during larval period, in later stage of development, similarly with the effects of malathion, the percentage of pupation and adult emergence decreased significantly (Figure.1). The mechanism in which the two insecticides interfered with the insect's body physiology was probably different. In order to study the effect of LD40 dosages of malathion and phosphamidon on tissue weight and different bioconstituents, the early instar larvae were allowed to feed on treated leaves and grow till adult. Analysis in late fifth instar larvae before silk spinning revealed that the tissue weight decreased along with total lipid, protein, Glycogen (female) and cholesterol (male) (Figure 2).

\section{Insecticide mechanism of action}

The major classes of synthetic pesticides are organochlorines, organophosphates, carbamates and pyrethroides. Preliminary survey revealed that organophosphates and pyrethroides are two of the most common pesticide classes used by common farmers against pests of paddy and other crops and vegetables in Assam. They also belong to the most commonly used pesticide groups in tea gardens. Organophosphates like malathion, phosphamidon and dimethoate even at sublethal dose have been reported to be highly toxic against the larvae of $A$. assama [6]. Organophosphates (OPs) are known to cause inhibition of esterases in silk worms [18]. Carboxylesterases constitute a class of the metabolic enzymes involved in insecticide resistance to OPs, carbamates, and pyrethroids through gene amplification, upregulation and coding sequence mutations [19]. The major function of acetylcholine esterase (AChE) is hydrolysis of the neurotransmitter acetylcholine bounded at cholinergic synapses in the central nervous system of insects [20] and the latter confers target site for susceptibility to orgnophosphorous insecticides which in Bombyx mori is reported to act through inhibition of $B m A C h E 1$ responsible for expression of acetylcholincholine esterase $[19,21,22]$. Like DDT, Pyrethroides are axonic poisons. But in contrast to the residual persistence and biomagnification effect of DDT for which its use in agricultural crop has been banned over the globe, pyrethroides are the fastest developing group of modern insecticides primarily because of their effectiveness and safety application [23]. The synthetic pyrethroid deltamethrin (Decis) although is effective against a notorious parasitoid of silk worm, Exorista sorbillans with LC50 value at $0.106 \%$, the insecticide has been found to be more highly toxic ( $\mathrm{LC} 50=9 \times 10^{-5}$ )to the larvae of muga silk worm, Antheraea assama [24]. Aerial application of organophosphates to agricultural field and their 
drifting to nearby mulberry plantation was reported to influence food consumption and utilization of silk worms [25]. Lipophilic insecticides are mainly carried in blood [26] in protein and protein associated forms [27]. From blood, insecticides are redistributed to gastrointestinal system, adipose tissue and brain [28-30]. Toxic effect of insecticides and oil pollutants are reported to cause changes in levels of different bioconstituents and metabolic processes in insects[30-34] finally leading to growth inhibition (Figure.1\& 2) [6,15,35].

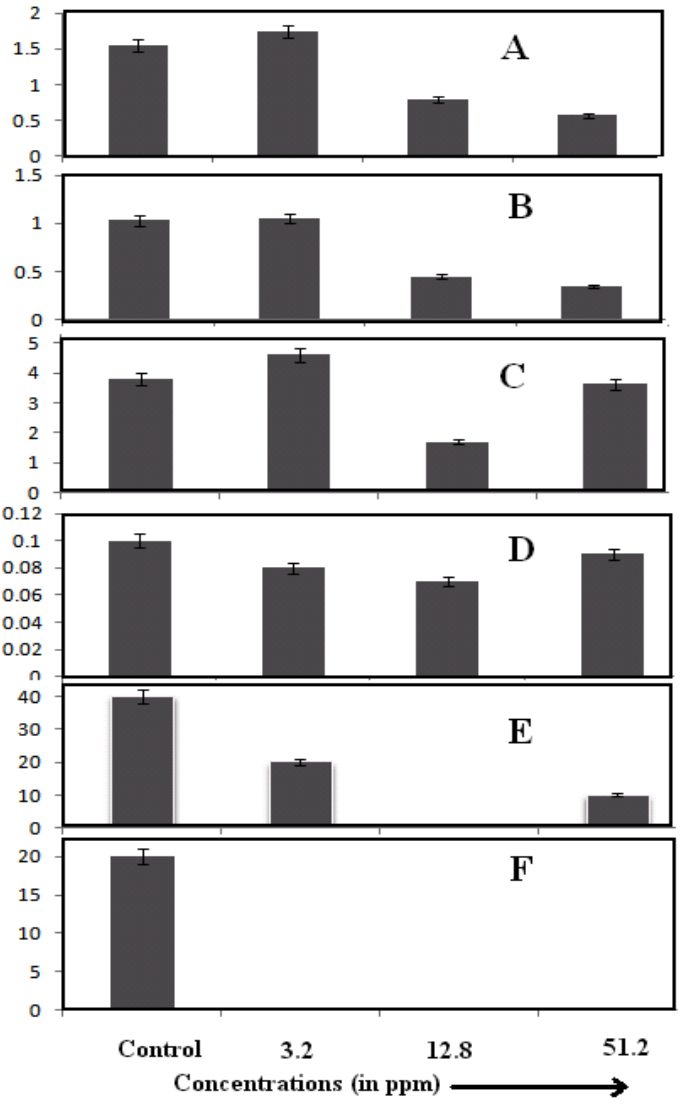

Malathion
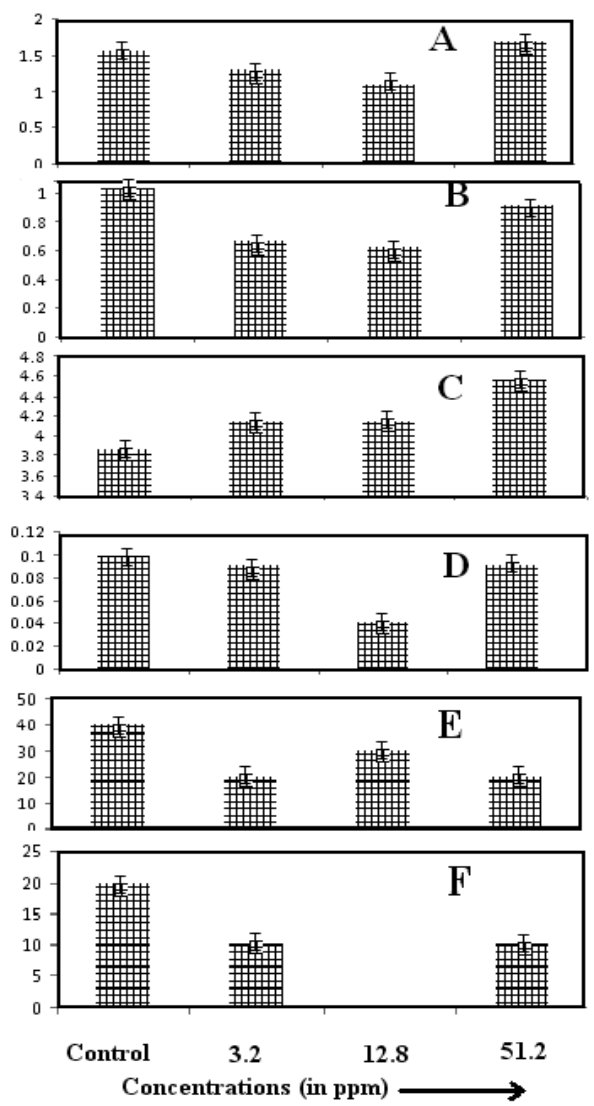

Phosphamidon

Figure 1. Effect of malathion and phosphamidon on developmental parameters of A. assama. A. Daily consumption, B. Daily utilization, C. Mean larval weight, D. Growth rate, E. Percentage of pupation, F. Percentage of emergence 


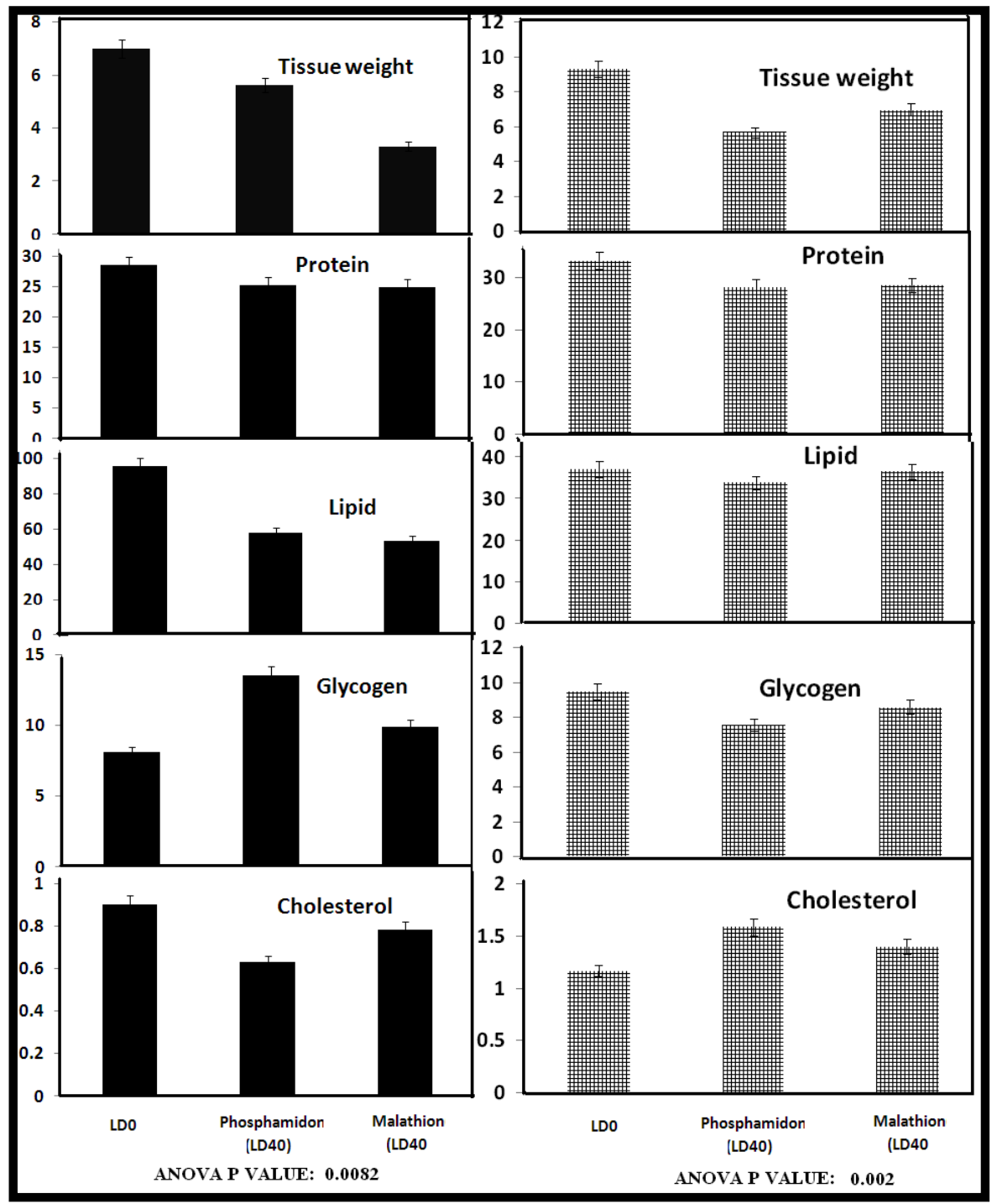

A B

Figure 2. Effect of phosphamidon and malathion on tissue weight and level of biochemical constituents, Tissue weight (mg), Total Protein (mg/weight), Total lipid (mg/ml), Glycogen (mg/ml)and cholesterol (mg/ml).A. Male, B. Female.

\section{Natural products}

Natural products are excellent alternative to synthetic chemical pesticides. Plants exhibit enormous versatility in synthesizing complex materials which have no immediate obvious 
growth or metabolic functions. These complex materials referred to as secondary metabolites are produced as constitutive and induced defense as a result of co evolution arising out of millions of years of plant-herbivore interaction [36-41]. They may be exploited for the management of insect pests owing to their ability to act as toxicant, repellent, antifeedant and insect growth regulators. They are non phytotoxic, biodegradable and have little or no mammalian toxicity [42,43]. Plant extracts and essential oils come under the category of "Green pesticides" as they are safe, eco friendly and more compatible with environmental components compared to synthetic pesticides. $20^{\text {th }}$ century witnessed an increasing trend in use of botanicals with more than 2000 bioactive plant species identified for their insecticidal and anti - pathogenic properties [39,40,44,45]. Natural insecticides such as pyrethrum, rotenone and nicotine have been used extensively for insect control [39]. Limnoids such as azadirachtin and gedunin, present in species from Meliaceae and Rutaceae are recognized for their toxic effects on insects and are used in several insecticide formulations in many parts of the world [46,47]. Neem formulations have been found effective against the mulberry hairy caterpillar, Eupterotemollifera Walker [48]. Pink mealy bug, Maconellicoccus hirsutus (Green) is one of the major pest which infests the mulberry plants and cause Tukra diseases leading to qualitative loss of leaves. Leaf extracts of Andrographis (99.0\%), Leucas leaf extract,NSKE (99.0\%), Vitex leaf and Ocimum (90.1\%) have been reported to act as repellent against the bug[49].

Grasserie (viral), Flacherie (bacterial), Muscardine (fungal) and Pebrine (protozoan) are four common diseases of silkworm and they have been causing heavy loss to silkworm crops in silk producing countries like India and China. Herbal extracts have been tried for control of these diseases. Isaiarasu et al. [50] reported efficacy of aqueous and alcoholic crude extracts of Acalypta indica, Ocimum sanctum and Tridax rocumbens against flacherie and muscardine diseases in silkworm. The alcoholic extract of the plant Tridax procumbens were reported most effective followed by alcoholic extract of Ocimum sanctum and Acalypta indica. The reported zone of inhibition (area $\mathrm{mm} 2$ ) of Acalypta indica, Ocimum sanctum and Tridax

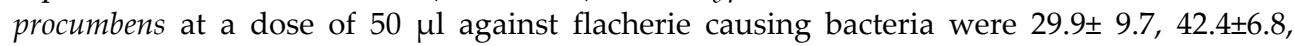
$74.6 \pm 6.6$ respectively and against muscardine causing fungus were 13.1 $\pm 6.3,23.6 \pm 3.4$, 23.1 \pm 9.1 respectively. Aqueous extracts of thirteen plants were tested against cytoplasmic polyhedrosis virus (AmCPV) in tasar silkworm, Antheraea mylitta and out of them $2 \%$ concentrations of Aloe barbedensis (AKP 3), Psoralea corylifoilia (AKP13) and Bougainvillea spectabilis (AKP 9) were reported effective in suppressing virosis. They reduced mortality of larvae due to virus infection of $66.17 \%, 64.47 \%$ and $57.19 \%$ respectively. Total haemocyte count and haemolymph protein were also reported to increase in treated larvae which is considered as expression of immune response against the attack of pathogen [51]. Extracts of Terminalia chebua has been recommended against a potent bacterial strain, Pseudomonas aerugenasa (strain AC3) causing flacherie disease in Antheraea assama [52].

\subsection{Plants of ethnic importance}

Indigenous knowledge (IK) is unique to a particular culture and society. IK is embedded in community practices, institutions, relationships and rituals [53]. It forms the basis for local decision-making in agriculture, health, natural resource management and other activities 
and constitutes an important component in the global knowledge system. In most cases, IK is an underutilized resource in the development processes [53]. Learning from indigenous knowledge of specific communities used for generations after generations can improve the understanding of their local conditions and saves time, effort and money besides constituting the foundation for activities designed to address regional and global problems. Thus, the natural products based on the indigenous use of botanicals could be one way of mitigating the problems associated with inappropriate use of synthetic chemicals [54].

\subsection{Botanicals in sericulture field}

In this chapter we restrict our discussions to candidate plants for being used against a parasitoids of silk worm. In sericulture field, farmers of Assam traditionally sprinkle extracts of tulsi (Ocimum sanctum) leaf over egg bunches (Kharika) of $A$. assama. No other plants were recorded to be used against pests and pathogens of this silkworm in a survey carried out in Upper Brahmaputra valley of Assam during 2007-2011. Uzi fly, Exorista sorbillans (Diptera: Tachinidae) is a parasitoid of silkworm and a serious threat to sericulture industry. The mated adult female fly lays eggs on the integument of third to fifth instar larva of Antheraea assama. The maggots after hatching pierce through the integument and grow inside the body of the silk worm by feeding on the fat body. The matured maggot pierce through the shell of the silk cocoon and crawl away from the site of the cocoonage in search of suitable place for pupation (Plate 2). The piercing of the cocoon shell renders the silk cocoon unreelable. In this way, the fly is reported to cause $20-80 \%$ loss of seed crop of $A$. assama. The fly infestation is reported in all the commercial silkworm varieties and from almost all silk producing countries of the world [55,56]. A total of ten plants possessing insecticidal and medicinal values including $O$. sanctum were bioassayed against E. sorbillans (Table 1). Leaves of the plants were shade dried, ground to fine powder and extracts were prepared by using ethanol, water and hydroalcohol (50:50). Ethanolic extract of three plants namely Catheranthus roseus, Ocimum sanctum and Ageratum conyzoides proved effective by causing $53.33 \%, 22.17 \%, 57.41 \%$ mortality after $24 \mathrm{~h}$ at $10 \%$ concentration. The order of toxicity was Ageratum conyzoides $>$ Catheranthus roseus $>$ Ocimum sanctum $>$ Melia azedarach $>$ Paederia foetida $>$ Eupatorium odoratum $>$ Polygonum hydropiper $>$ Vitex negundo=Leucas aspera.

Further fractionation of ethanolic extract of the effective plants using an eleutropic series of solvents viz. petroleum ether, chloroform, butanol and water followed by subsequent bioassay showed that the petroleum ether extract of Catheranthus roseus, Ocimum sanctum and Ageratum conyzoides caused $46 \%, 6.67 \%, 86.21 \%$ respectively after $24 \mathrm{~h}$ and $100 \%$, $33.79 \%, 100 \%$ mortality respectively after $48 \mathrm{~h}$ at $5 \%$ concentration. Results of other solvent fractions were found negligible. The LC50 value of the most effective petroleum ether extract of Ageratum conyzoides was recorded as 0.74 percent [57]. Qualitative phytochemical studies of petroleum ether extract of the plants showed positive results for the presence of flavonoids, alkaloids, phenols and terpenoids. Ocimum sanctum has been reported to be effective against other Dipterans and many other pests and microorganisms[58-61]. In addition to Ocimum the other two plants found effective were Ageratum conyzoides (Asteraceae) and Catharanthus roseus(Apocynaceae). Extracts of different species belonging to Asteraceae were earlier found effective against mosquitoes. Ageratum conyzoides with a 
long history in medicinal use is a common weed species and naturally grows in abundance in Assam. It is widely distributed in tropics and subtropics and has been used in various parts of Africa, Asia and in South America for curing various diseases like purulent ophthalmia, ulcers, wound caused by burns, asthma, dyspnea, pneumonia and also as purgative, febrifuge, antiinflammaory, analgesic, anti-diarrheic etc. Both essential oil and the major component precocene have antijuvenile hormone activity on a variety of insects [62]. In addition to their medicinal importance Catharanthus roseus has been reported effective against many insect pests including Dipterans. Volatile components obtained by hydrodistillation was found to contain 76 compounds [63].

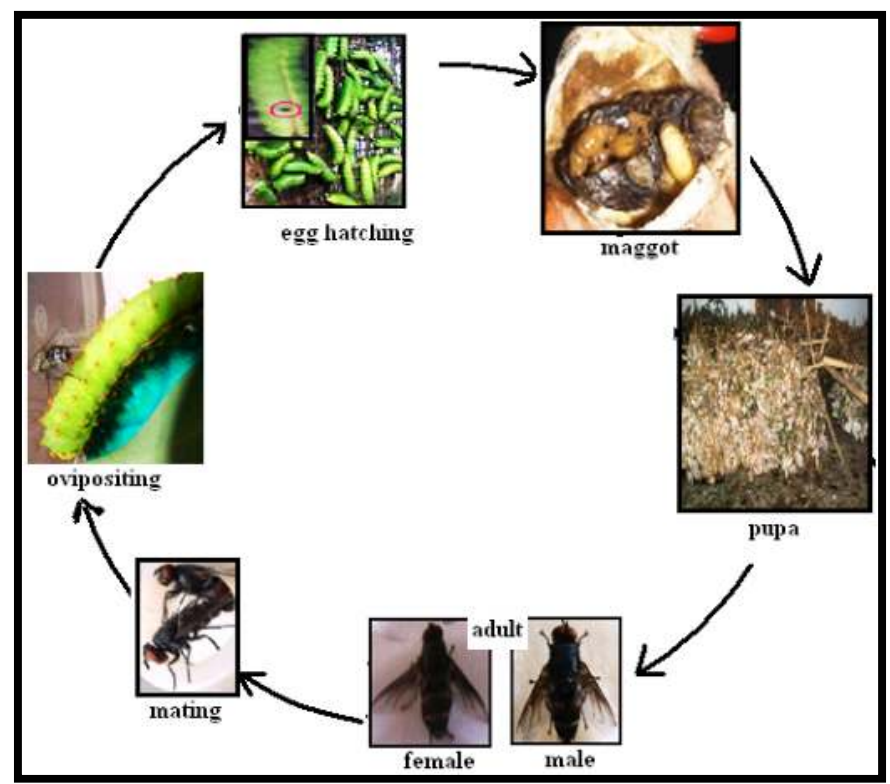

Plate 2. Life Cycle of Exorista sorbillans (Uzi fly)

\begin{tabular}{|l|l|l|l|l|l|}
\hline $\begin{array}{l}\text { Sl. } \\
\text { No. }\end{array}$ & Plant & $\begin{array}{l}\text { Cold water } \\
(\text { Mean } \pm \text { SE })\end{array}$ & $\begin{array}{l}\text { Hot water } \\
(\text { Mean } \pm \text { SE })\end{array}$ & $\begin{array}{l}\text { Hydroalcohol } \\
(\text { Mean } \pm \text { SE })\end{array}$ & $\begin{array}{l}\text { Ethanol } \\
(\text { Mean } \pm \text { SE })\end{array}$ \\
\hline 1. & O.sanctum & $0 \pm 0$ & $3.33 \pm 3.33$ & $3.33 \pm 3.33$ & $22.17 \pm 4.54$ \\
\hline 2. & O.gratissimum & $0 \pm 0$ & $13.33 \pm 3.33$ & $6.67 \pm 3.33$ & $15 \pm 5.01$ \\
\hline 3. & A.conyzoides & $0 \pm 0$ & $10 \pm 5.78$ & $13.70 \pm 3.17$ & $57.41 \pm 4.31$ \\
\hline 4. & C.roseus & $0 \pm 0$ & $3.33 \pm 3.34$ & $3.33 \pm 3.34$ & $53.33 \pm 21.88$ \\
\hline 5. & E.odoratum & $0 \pm 0$ & $3.33 \pm 3.34$ & $0 \pm 0$ & $3.33 \pm 3.34$ \\
\hline 6. & L. aspera & $0 \pm 0$ & $0 \pm 0$ & $0 \pm 0$ & $0 \pm 0$ \\
\hline 7. & M.azedarach & $0 \pm 0$ & $0 \pm 0$ & $0 \pm 0$ & $6.67 \pm 3.3$ \\
\hline 8. & P.foetida & $0 \pm 0$ & $10 \pm 0$ & $0 \pm 0$ & $3.33 \pm 3.34$ \\
\hline 9. & P.hydropiper & $0 \pm 0$ & $3.33 \pm 3.34$ & $0 \pm 0$ & $0 \pm 0$ \\
\hline 10. & V.negundo & $0 \pm 0$ & $0 \pm 0$ & $0 \pm 0$ & $0 \pm 0$ \\
\hline
\end{tabular}

Table 1. Comparative toxicity of crude extracts of plants (10\%) to E.sorbillans (contact residual film technique) 


\subsection{Botanicals in paddy cultivation}

Farmers in some locations of Brahmaputra valley of Assam use plant materials in rice fields for prevention of pest infestation. For instance, robub tenga (Citrus maxima), chuka tenga (Citrus medica), jora tenga (Citrus spp.), leaf of baghdhaka (Chromolaena odorata), patharua bihlongoni (Polygonum hydropiper), chirata tita (Andrographis paniculata) etc. But, no systematic study has been carried out so far to ascertain if farmers are deriving any benefit or there is any scientific basis behind the beliefs of the farmers. A survey done by interactions with 200 farmers in 44 villages revealed that $23 \%$ farmers used synthetic chemical pesticides, 37\% used traditionally used plant parts, $27 \%$ used both synthetic chemicals and traditionally used plant parts, while 13\% adopted neither synthetic chemicals nor traditionally used plant materials (Table 2) [64].

Similarly with the discussions in context with pests and their control in sericulture field, here we limit our discussions regarding traditional use of plants and their scientific validation in context with a representative pest of paddy. Nymphula depunctalis (Guenée) [=Parapoynx stagnalis (Zeller)] (Lepidoptera; Pyralidae) is a serious pest of paddy that attacks young rice plants in waterlogged paddy fields of the Oriental region [ 65-70].It also thrives on various other grasses [71]. A number of related species occur in Asia but N. depunctalis is most widely distributed occurring in South and South East Asia, China, Japan, Australia, South America and Africa [72-74]. In many parts of Asia, N. depunctalis has been reported as a major pest [75-79]. In India, it is one of the serious pests in the states of Andhra Pradesh, Assam, Bihar, Karnataka, Orissa, Tamil Nadu, Manipur and Kerala. Damage to the plant occurs mainly due to defoliation by scraping of the green tissues by the larvae leaving only the white papery epidermis behind. Upon hatching, the first instar larvae climb onto a leaf and begin feeding on the green tissues by scraping the leaf surface. They then move to the leaf tip and cut a slit on the margin at a location $2-3 \mathrm{~cm}$ below the leaf tip. Then they make another cut about $1 \mathrm{~cm}$ below the first cut. Due to a lack of turgor pressure, the cut leaf segment rolls around a feeding larva to form a tubular case that is secured by silk spun by the larva. The inner surface of the leaf case is lined with silk to hold a thin film of water that is essential for respiration and to prevent desiccation of the larva[80]. Pupal period is spent within a closed case. (Plate 3).

Twenty two plants were found to be used traditionally in paddy fields against $N$. depunctalis and out of them extracts of 13 plants were selected for bioassay against $N$. depunctalis. The methods used for bioassay were residual film technique [81] and case dip technique [82]. The selected plant parts were shade dried, ground to powder and used to prepare extracts using water, hydro-alcohol (50:50) and ethanol. While hot water extract was the least toxic, both hydro-alcohol and ethanolic extracts were highly toxic. Out of thirteen plants tested, ethanol extract of seven plants were found highly effective (90 - $100 \%$ mortality), five plant extracts were found moderately effective (50 - 89\% mortality) and one was found the least effective (mortality less than 50\%). The highly effective ones were leaves of Calotropis procera, root-bark of Zanthoxylum nitidum, leaves of Zanthoxylum rhesta, stem bark of Crataeva nurvala and leaves of Croton tiglium, Vitex negundo and Chromolaena odorata. 
The moderately effective ones were leaves of Melia azedarach, Dryopteris filix-mass, Polygonum hydropiper and Tephrosia candida, roots of P. hydropiper. Leaf of Premna latifolia was found the least effective. The degree of toxicity of the effective plants were Calotropis procera > Zanthoxylum nitidum > Zanthoxylum rhesta using residual film technique. The degree of toxicity in bioassay using case dip technique was Calotropis procera $>$ Zanthoxylum nitidum $>$ Zanthoxylum rhesta $>$ Crataeva nurvala $>$ Croton tiglium $>$ Vitex negundo $>$ Chromolaena odorata. Phytochemical analysis for alkaloid, flavonoid, tannin, saponin, sterol and glycosides using crude ethanol extract showed the presence of flavonoid, tannin, saponin and glycoside in leaf extract of Calotropis procera; flavonoid, saponin, sterol and glycoside in the leaf extract of Chromolaena odorata; alkaloid, flavonoid, tannin and sterol in the stem-bark extract of Crataeva nurvala; flavonoid, tannin and sterol in the leaf extract of Croton tiglium; tannin and sterol in the leaf extract of Vitex negundo; alkaloid and sterol in the root-bark extract of Zanthoxylum nitidum and flavonoid, tannin, saponin and glycoside in Zanthoxylum rhesta. (Figure 1 and 2)[59].

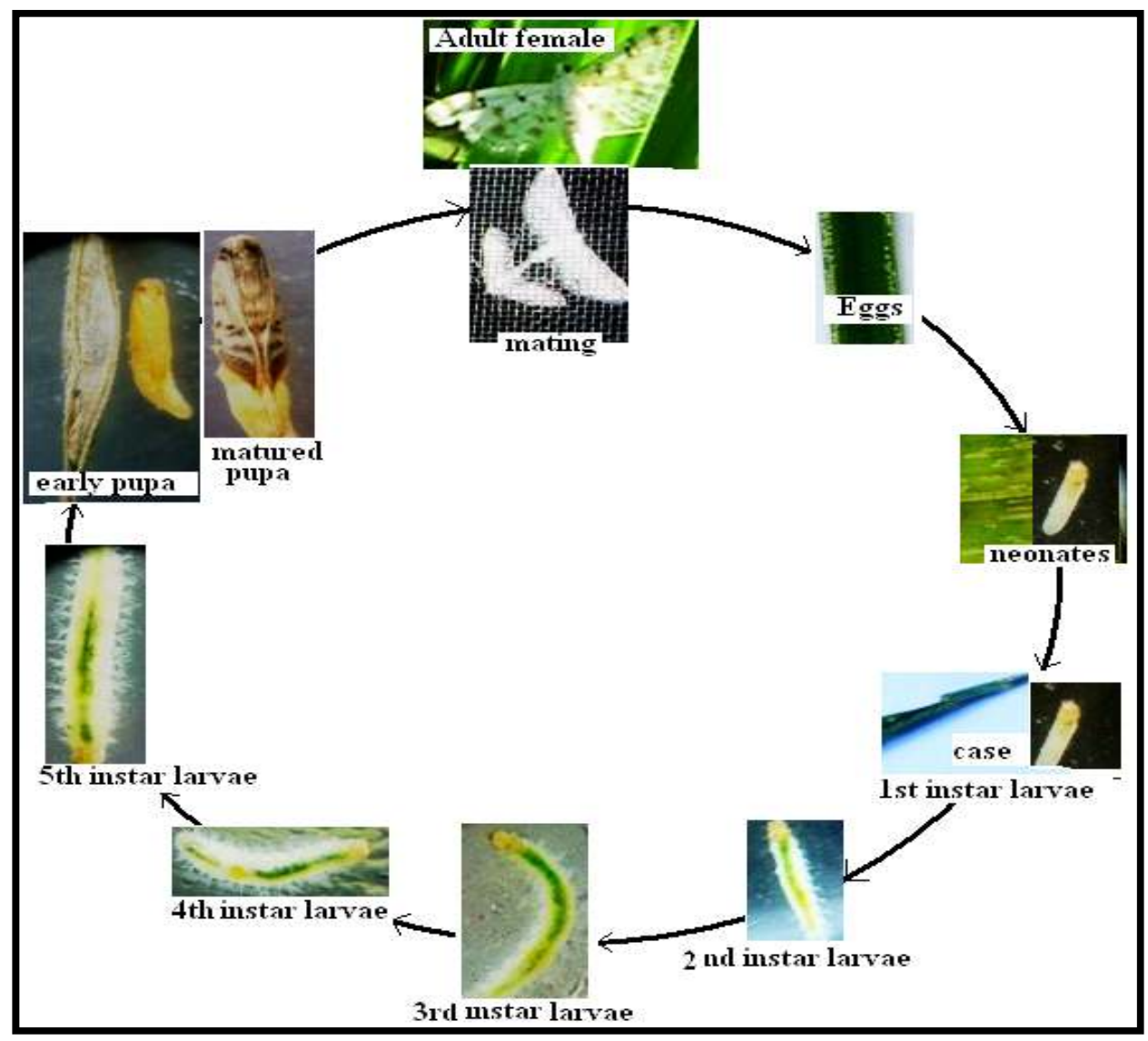

Plate 3. Life cycle of Nymphula depunctalis 


\begin{tabular}{|l|l|l|l|l|}
\hline Scientific Name & Common Name & Family & Part Used & $\begin{array}{l}\text { Farmer } \\
\text { s in } \%\end{array}$ \\
\hline Ageratum conyzoides & Gundhua ban & Asteraceae & Leaf (LF) & 01.0 \\
\hline Andrographis paniculata & Chirata & Acanthaceae & Leaf & 03.0 \\
\hline Azadirachta indica & Mahaneem & Meliaceae & Leaf and Seed & 05.5 \\
\hline Calotropis procera & Akan & Asclepiadaceae & Leaf and stem & 04.0 \\
\hline Chromolaena odorata & Germany ban & Asteraceae & Leaf & 42.0 \\
\hline Citrus grandis, C. medica & Rebab and Bor & Rutaceae & Fruits and Fruit peel & 11.5 \\
\hline Colocasia spp. & Tenga & & & \\
\hline Crataeva nurvala & Varun & Araceae & Stem & 01.5 \\
\hline Croton tiglium & Koni bih & Capparidaceae & Stem-Bark (SB) & 03.5 \\
\hline Cympogon nardus & Citronella & Euphorbiaceae & Leaf and Seed & 03.0 \\
\hline Dryopteris filix-mas & Dhekia bilohngoni & Aspidiaceae & Leaf & 01.5 \\
\hline Euphorbia neriffolia & Siju & Cactaceae & Stem & 03.0 \\
\hline Jatropha gossypifolia & Bhoot ara & Euphorbiaceae & Leaf and Stem-Bark & 03.0 \\
\hline Melia azedarach & Ghora neem & Meliaceae & Leaf & 05.0 \\
\hline Murraya koeningii & Narasinga & Rutaceae & Leaf & 00.5 \\
\hline Polygonum hydropiper & Patharuabihlongoni & Polygonaceae & Leaf, Stem, Root (RT) & 07.5 \\
\hline Premna latifolia & Pitha & Lamiaceae & Leaf & 21.00 \\
\hline Tephrosia candida & Kuku mah & Fabaceae & Stem-Bark and Leaf & 06.0 \\
\hline Thevetia nerrifolia & Rakta karabi & Apocynaceae & Stem-Bark, Seed & 02.00 \\
\hline Vitex negundo & Pasatia & Verbenaceae & Leaf & 13.00 \\
\hline Zanthoxylum nitidum & Ricom, Tezmui & Rutaceae & Root-Bark (RB) & 03.00 \\
\hline Zanthoxylum rhesta & Ongare & Rutaceae & Leaf and Stem Bark & 02.00 \\
\hline
\end{tabular}

Table 2. List of plants used by the farmers against insect pests of paddy in North East India

\subsection{Botanicals in tea gardens}

Tea, Camellia sinensis (L.) O. Kuntze is grown in a monoculture system and about 1031 arthropod species are reported to be associated with the crop [83]. Cultivation and production of Assam tea was started by Assam company under the British regime around 1840 and the company monopolized the industy till 1860. With the advent of synthetic pesticides and their tremendous potentiality for controlling insect pests, during 50's tea industries started applying insecticides against tea pests which boosted production [83].With the growing concern over pesticidal residue in tea leaves and environmental impact of pesticides, various international regulatory bodies have fixed maximum permissible limit of residues in tea leaves. Synthetic pesticides are still being used in tea plantations although in limited quantity. These pesticides however do not remain confined to the tea plantations only and contaminate the host plants of silkworms grown in sericulture fields lying adjacent to the tea gardens[6]. Literature reveals that several plants have been found to be effective against pests of tea [83-86]. 


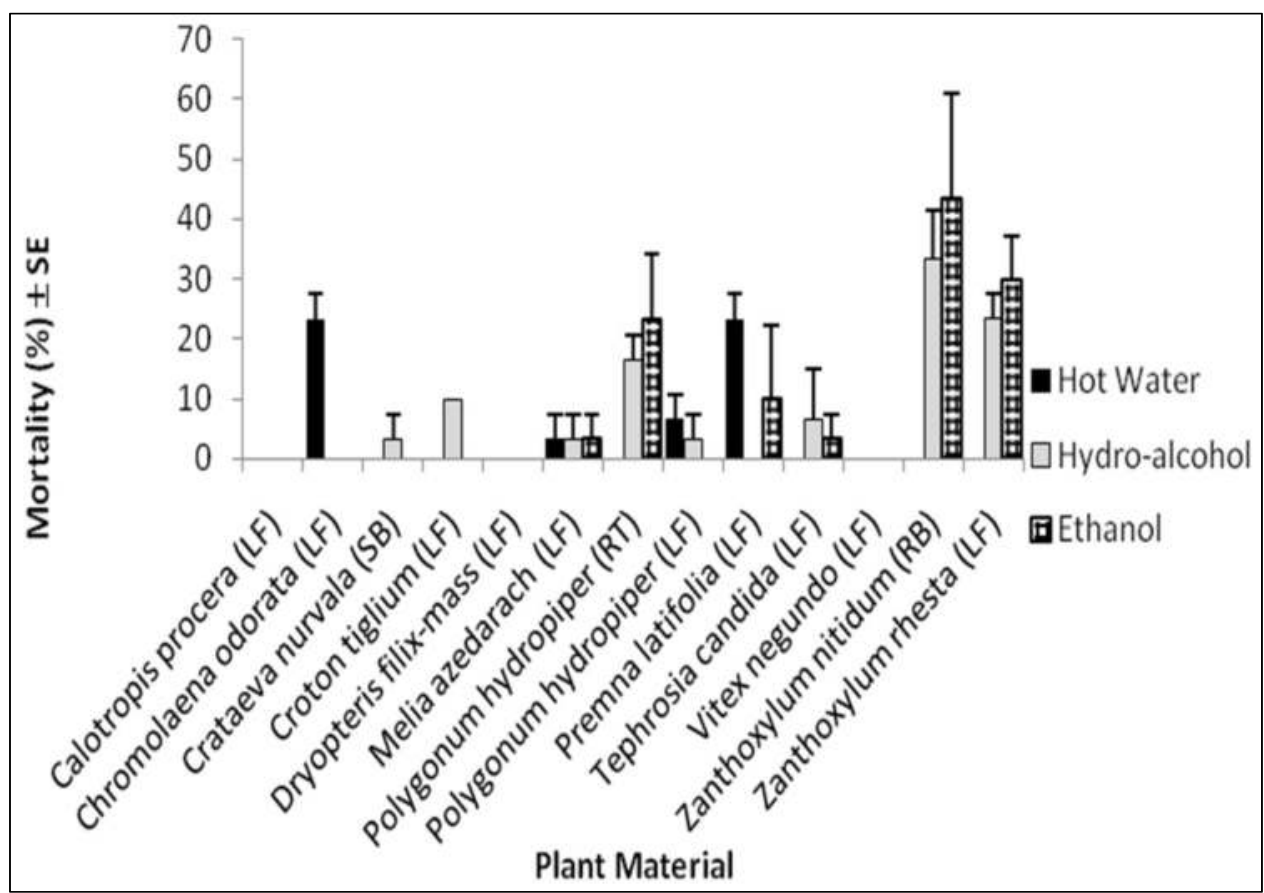

Figure 3. Effects of plant extracts on percent mortality of larvae of $N$. depunctalis in residual film technique

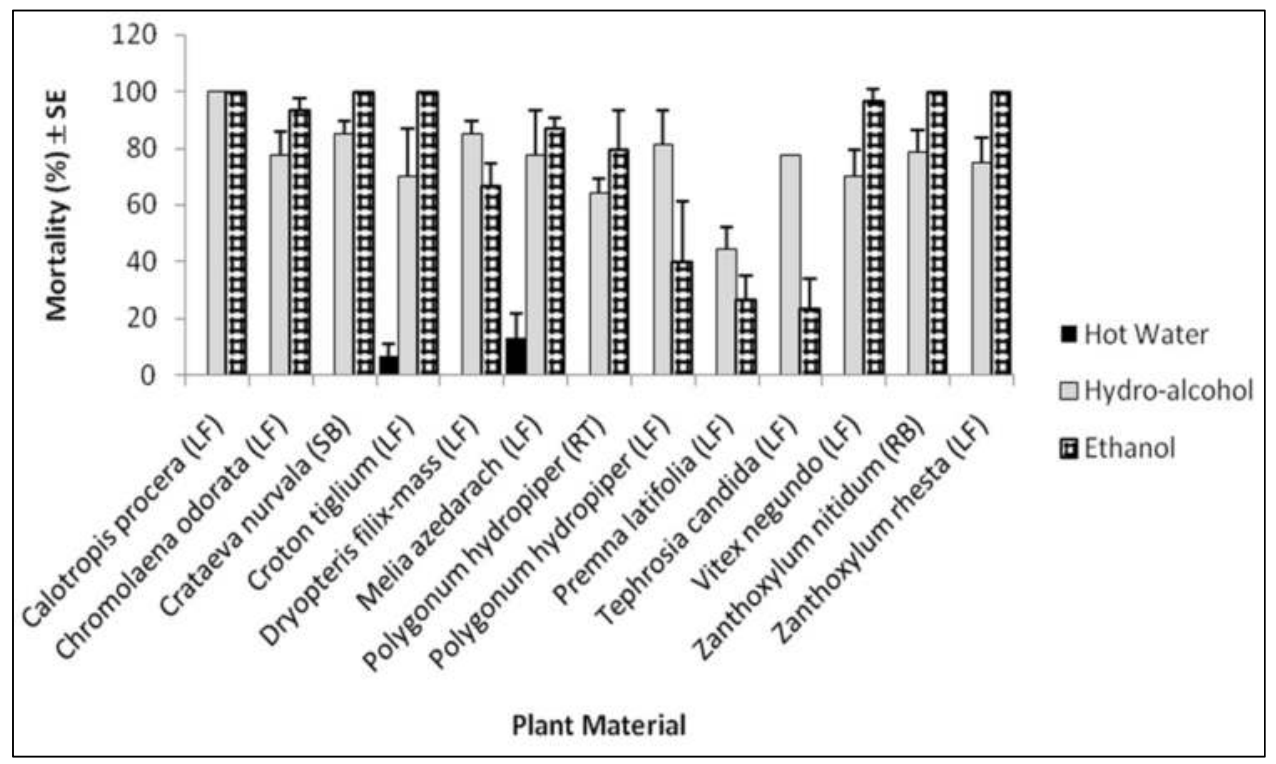

Figure 4. Effects of plant extracts on percent mortality of larvae of $N$. depunctalis in case dip technique. 


\section{Selective toxicity of plant products}

Integrated pest management emphasizes on use of pesticides having selective toxicity as against the use of broad spectrum pesticides. This reminds us of classical examples of using different insecticides for controlling aphids and thrips in potted chrysenthemum in glass houses of Southern Britain in 70's at the advent of development of the concept of integrated pest management [87]. Apart from the aspects why plant products are considered better options for pest control as discussed above, if they can be categorized for having differential efficacy against different insects, the latter can give an added value to plant products for being used in pest control. However the efficacy also depends not only on the compound(s) present in the plant preparation but also on the ability of the insect to defend against the compounds they are subjected to. Less tissue susceptibility, presence of detoxifying enzyme, high immune response, development of alternative physiological pathways, reduced penetration of pesticides through the cuticle and intestine, lower transport of pesticides to the target sites, storage of pesticides in fat body or other inert organs, genetically determined modified behavior in response to pesticide etc. may be factors responsible for conferring resistance to certain insects against high susceptibility of other insect species [ 23,88.89].

Silk worms have a bitrophic relationship with the Dipteran, Exorista sorbillans (Widemann) (Uzi fly) as the later is an endoparasitoid of the silk worm. As silkworms are beneficial insects, before recommending use of any botanical it is desirable to investigate whether the recommended plant or its product found effective against pest and pathogens in seriecosystem possess selective toxicity or not. An investigation carried out to evaluate selective efficacy of petroleum ether extract of certain plants against the component insects of the bitrophic system, Exorista sorbillans and larvae of A. assama revealed no mortality of late instar larvae of A. assama till $48 \mathrm{~h}$ at $10 \%$ concentration while they were highly toxic to the parasitoid Exorista sorbillans.

Essential oils are volatile mixtures of hydrocarbons with diverse functional groups. Essential oils are defined as any volatile oil(s) that have strong aromatic components and that give distinctive odour, flavor or scent to a plant. These are the byproducts of plant metabolism and are commonly referred to as volatile plant secondary metabolites. Essential oils are found in glandular hairs or secretory cavities of plant cell wall and are present as droplets of fluid in the leaves, stems, bark, flowers, roots or fruits in different plants. The aromatic characteristic of essential oils attract or repel insect, protect plant from heat or cold and the chemical constituents of the oil act as defense material. Their probable diverse mode of action and use in food and pharmaceutical industry justify their status as possible environmentally benign candidate for pest management. O.sanctum and A.conyzoides are plants with rich source of essential oils. The toxicity of these oils were evaluated by both contact residual and topical application method against the parasitoid of silkworm, E.sorbillans. These oils were found more effective than petroleum ether extract of the respective plants and the calculated LC50 value of essential oil of O. sanctum and $A$. conyzoides in contact residual film method were recorded as $0.15 \%$ and $0.05 \%$ respectively. 
But, topical application of the oil showed a different order of toxicity and reflected the fact that degree of toxicity depended on method of application. The Lethal time for O. sanctum oil was $4 \pm 0.58$ minutes and that of $A$. conyzoides oil was $118 \pm 12.45$ minutes after topical application of $1 \mu \mathrm{l}$ of oil on thorax of the fly and hence degree of toxicity of oil on topical application was $O$. sanctum $>A$. conyzoides. When toxicity of these oils were compared against the larvae of $A$. assama, it was found that late instar larvae could survive till $48 \mathrm{~h}$ after application of $0.5 \%$ concentrations of oil of the plants. The same concentration of oil of $A$. conyzoides while were applied against early instar larvae $100 \%$ mortality was caused with LC50 value at $0.19 \%$ concentration(Table 3)[81]. But toxicity of oil of O. sanctum against A.assama larvae was lower and at 0.5 percent concentration, it could only cause a maximum of $5.78 \%$ mortality of early instar larvae at $48 \mathrm{~h}$ of treatment and could cause no mortality in late instar larvae till $48 \mathrm{~h}$ of observation period (Figure 5). This may suggest less tissue sensitivity of Antheraea assama against the action of extract and oil of O. sanctum applied [90]. The plant Ocimum spp. is known to comprise more than thirty species, but only a few have been subjected to phytochemical studies (Grayer et al. 1996). The whole plant of Ocimum is rich in essential oil and based on composition of volatile principles of essential oil, intraspecific chemotypes of several species of Ocimum have been described[91-93]. The plant is a part of Indian tradition as a holy substance and its essential oil is larvicidal against both Aedes and Culex mosquitoes [94].

\begin{tabular}{|l|l|l|l|l|l|l|}
\hline $\begin{array}{l}\text { Plant } \\
\text { material }\end{array}$ & Exorista sorbillans & & & Antheraea assama & & \\
\hline & Regression equation & $\begin{array}{l}\text { LC50 } \\
(\%)\end{array}$ & $\begin{array}{l}95 \% \\
\text { Fiducial } \\
\text { limit }\end{array}$ & Regression equation & $\begin{array}{l}\text { LC50 } \\
\%)\end{array}$ & $\begin{array}{l}95 \% \\
\text { Fiducial } \\
\text { Limit }\end{array}$ \\
\hline $\begin{array}{l}\text { A. conyzoides } \\
\text { oil }\end{array}$ & $\mathrm{Y}=8.72+2.87 \mathrm{X}$ & 0.05 & $2.603-3.075$ & $\mathrm{Y}=7.10663+2.92014 \mathrm{X}$ & 0.19 & $2.394-2.837$ \\
\hline $\begin{array}{l}\text { O.sanctum oil } \\
\mathrm{Y}=9.15452+4.97895 \mathrm{X}\end{array}$ & 0.146 & $8.929-11.172$ & - & - & - \\
\hline $\begin{array}{l}\text { A.conyzoides } \\
\text { petroleum } \\
\text { ether }\end{array}$ & $\mathrm{Y}=5.17654+1.27665 \mathrm{X}$ & 0.72 & $1.220-1.352$ & $\mathrm{Y}=3.62422+0.625415 \mathrm{X}$ & 154.88 & $0.311-0.937$ \\
\hline Deltamethrin & $\mathrm{Y}=5.90148+.904456 \mathrm{x}$ & 0.103 & $1.688-1.969$ & $\mathrm{Y}=7.46583+.612381 \mathrm{x}$ & .00009 & $0.572-0.656$ \\
\hline
\end{tabular}

Table 3. Efficacy of extract \& oil of A. conyzoides and O. sanctum as compared with Deltamethrin [ (_) in cells indicate zero mortality].

\subsection{Identification of haemocytes of A.assama by light microscopic and transmission electron microscopic studies (TEM) studies}

In order to understand the possible effects of the extracts of $O$. sanctum and A. conyzoides at cellular level electron microscopic studies of haemocytes were carried out after topical application of the extracts on thoracic surface of fifth instar larvae of $A$. assama.Five types of haemocytes of A.assama were identified under light microscopic and transmission electron 
microscopic studies. The identified cells were-1. Plasmatocyte 2.Granulocyte 3.Spherulocyte 4. Prohaemocyte 5. Oenocyte (Plate-4-9)

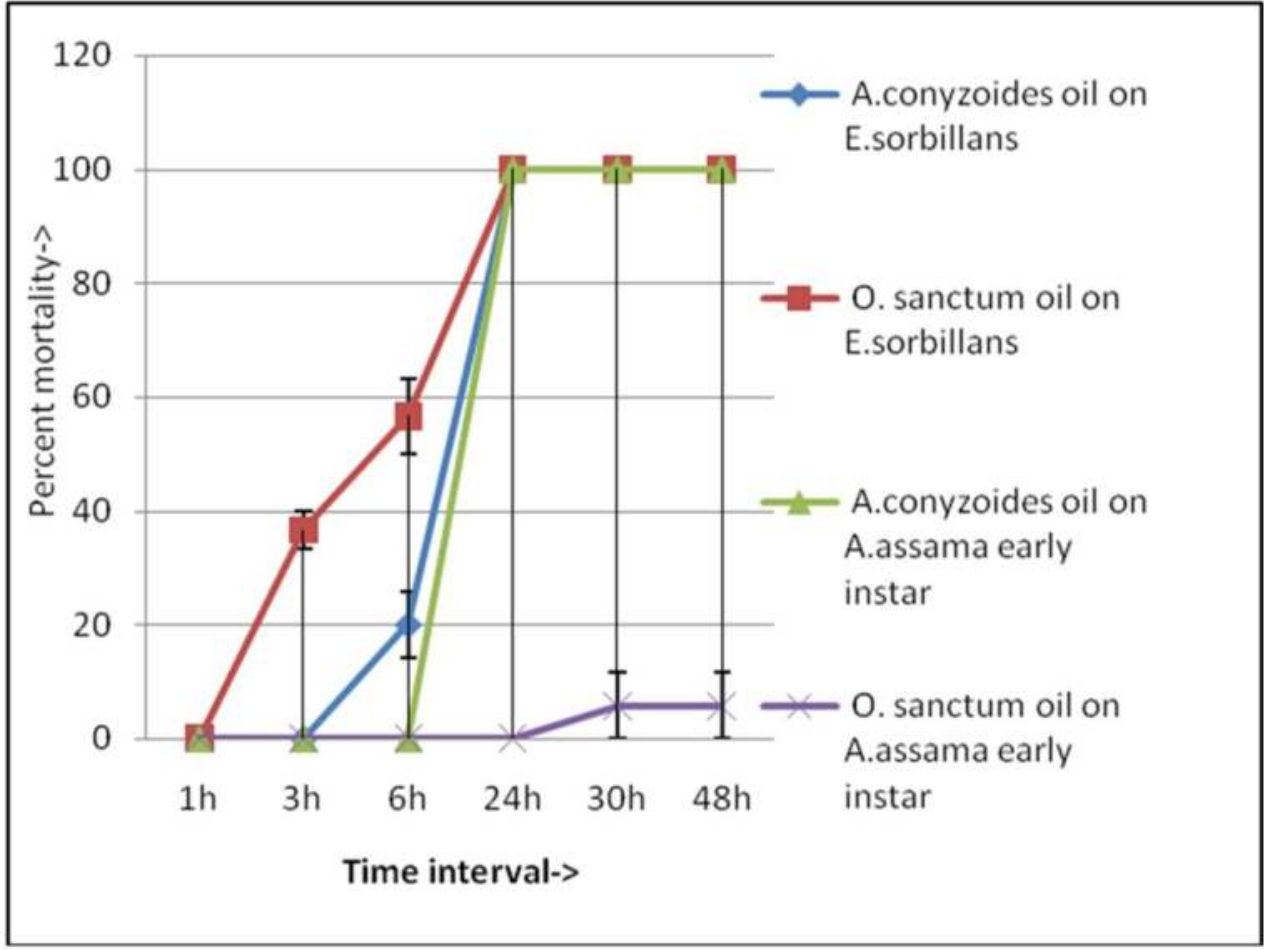

Figure 5. Comparative percent mortality of A. assama and E. sorbillans at $0.5 \%$ concentration of oil of O. sanctum and A. conyzoides

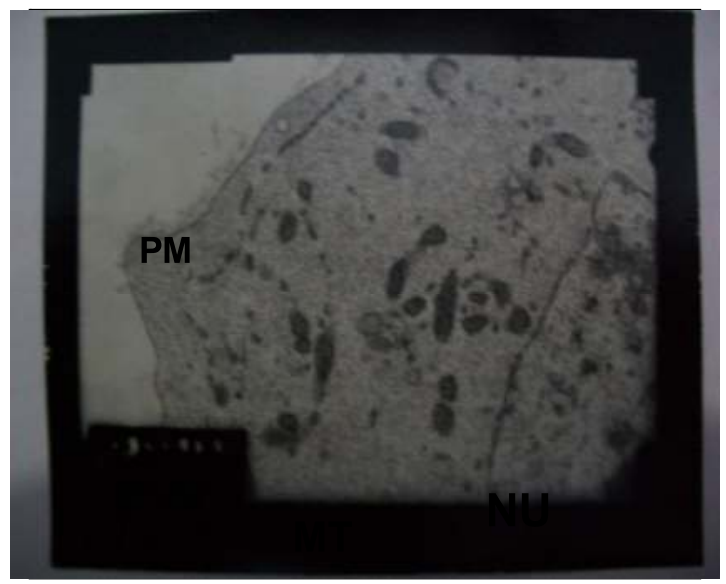

Plate 4. Plasmatocyte in A. assama 


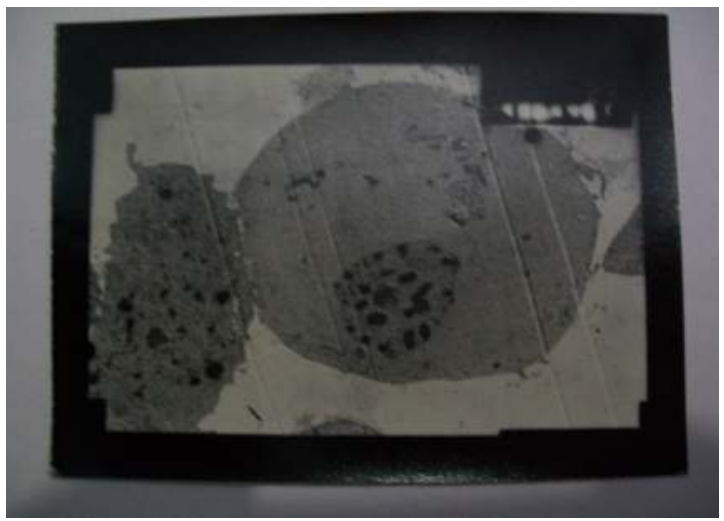

Plate 5. Plasmatocyte and Oeonocyte

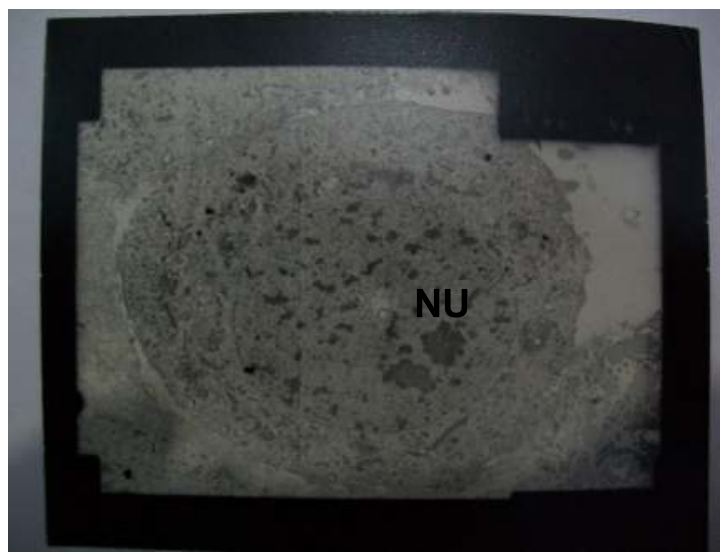

Plate 6. Prohaemocyte of $A$. assama

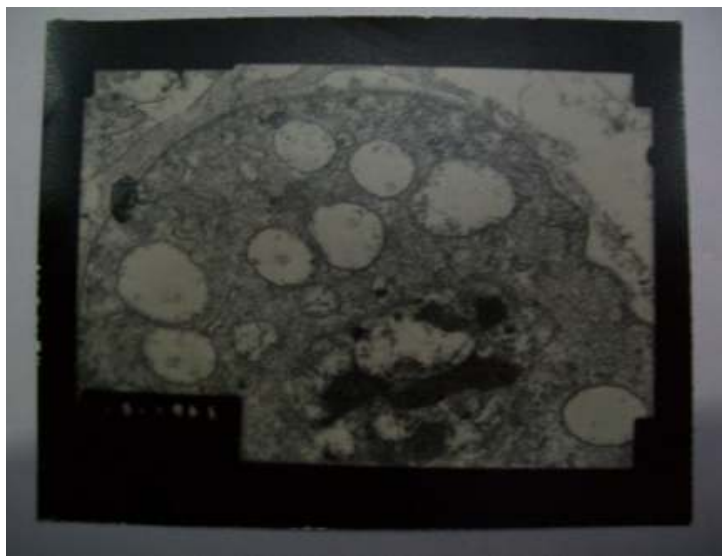

Plate 7. Spherulocyte of A.assama 


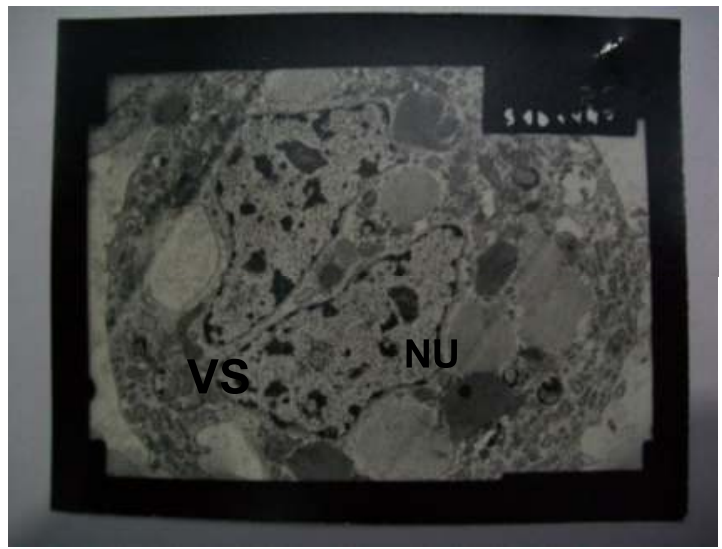

Plate 8. Granulocyte of A.assama under TEM

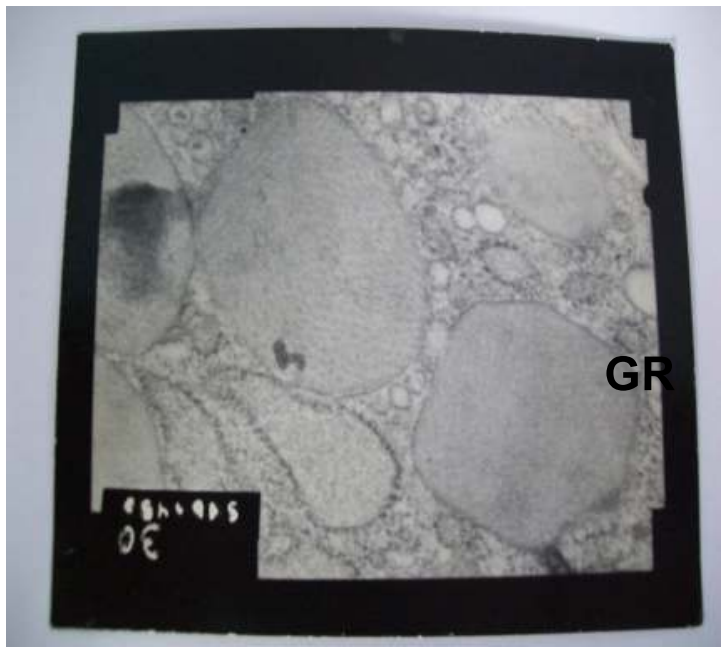

Plate 9. Structured granule

\subsubsection{Plasmatocyte}

Plasmatoytes are polymorphic cells with round, ovoid, elongate and spindle shaped structures with filopodia. The cells are small to moderate size. The long axis is $25 \mu \mathrm{m}$ and the short axis is $14.74 \mu \mathrm{m}$. Surface of PLs is not smooth and have ridges much flatter than those of granulocytes. Nucleus is dense, round, ovoid or elongated with distinct membrane. The cytoplasm is generally abundant, granular and agranular. Cytoplasm contains a good number of mitochondria and extensive rough endoplasmic reticulum. Golgi body recorded was in less number. Vacuole is rare in normal cell. The nucleus is mostly centrally placed, prominent, usually round but changes shape with the change in shape of the cell. 


\subsubsection{Granulocyte}

They are rounded or oval in shape with long and short filopodia. The long axis is $8.382 \mu \mathrm{m}$. Two types of membrane bound granules were observed, electron dense and structured. Cytoplasm contains large number of mitochondria, endoplasmic reticulum, free ribosomes, lysosomes and small number of vacuoles. Binucleate granulocyte was also recorded. Nucleus generally small takes various shapes, round, ovoid or irregular. The cell surface contains many elevations and depressions giving a conspicuous pattern.

\subsubsection{Spherulocyte}

These are spherical or ovoid or elongated cells with long axis $7.21 \mu \mathrm{m}$. The cell surface contains pits. Wavy edges show presence of spherules. Nucleus is mostly centrally placed, sometimes obscured by spherules. Mitochondria, rough endoplasmic reticulum and golgi complex were observed in cytoplasm when spherule number was less.

\subsubsection{Prohaemocyte}

They are round, oval in shape and long axis is $7.94 \mu \mathrm{m}$. The nucleus occupies major area of the cell. Plasma membrane is almost smooth. Cytoplasm is thin, almost homogeneous, contains few number of mitochondria, Golgi bodies and endoplasmc reticulum. SEM shows a spherical surface.

\subsubsection{Oenocytoid}

These are large rounded or ovoid cells with eccentric nucleus. Nucleus is small, nucleoli were prominent. The plasma membrane is smooth and regular. Cytoplasm uniformly distributed and contains extensive rough endoplasmic reticulum. Filopods are generally absent. Other cellular organelles like Golgi bodies and mitochondria are less in number.

\subsection{TEM studies on effect of petroleum ether extract on haemocytes of late instar larvae}

Transmission electron microscopic studies of haemocytes of fifth instar silk worm larvae was done after application of petroleum ether extracts of $O$. sanctum and A. conyzoides at different hours of treatment (Plates 10-21).

Application of petroleum ether extract of $O$. sanctum at $0.25 \mathrm{~h}$ caused less damage of PL and GR. Mitochondria and nucleus was almost intact in both types of cells. Nuclear membrane and cell membrane damage was negligible. Cell attachment was less in number. Release of material from GR was observed in some points. Golgi body was in formative phase in GR. PL cells in dividing stage and dividing nucleus in GR was recorded.

Cell membrane breakdown of PL was observed at $1 \mathrm{~h}$ of treatment while mitochondria was intact. Filopods are less. But cell attachment was marked. GR cell was less affected and 
filopod like extension was many toward cell attachment site. Granules were released from the area of damage of the cell membrane. Dissolution of nuclear membrane was observed at certain points. OE, SP, PRO was less affected. At $6 \mathrm{~h}$ of treatment PLwas less affected. Golgi body was observed at formative phase. Filopods are less in number. Export of material from the cell was observed. GR cell was also less affected. Cell membrane, mitochondria were well preserved. Nucleus in dividing stage was recorded. In some GR, granules release from the cell. Some GR attach to one another. Other cells are less affected. But at $12 \mathrm{~h}$ of treatment period, cell membrane breakage, mitochondrial damage vacuolization of PL cell was observed while GR cell was less affected. But again at $48 \mathrm{~h}$ no effect on cell membrane, nuclear membrane, mitochondria was observed. Golgi was found to be in formative stage. Release of material was not recorded. GR cell was looking intact where cell membrane, mitochondria and nuclear membrane were not affected. Aggregation of cell was less. OE cell membrane was ruptured and released some cytoplasmic materials but mitochondria, nuclear membrane were well preserved. Attachment of OE with other cells was observed. SP and PRO were less affected.

At $0.25 \mathrm{~h}$ of $A$. conyzoides petroleum ether extract treatment, heavy loss of the cell membrane of PL cell was noticed but mitochondrial structure was found almost in good condition. ER long while many Golgi bodies were found in formative stage casting off numerous vesicles. Cell attachment was very pronounced with release of flocculent material. Many vesicles were observed in cytoplasm. Extensive damage of the cell membrane of GR cell was observed. Some of the mitochondria was found in a state of completely dissolved mitochondrial membrane. But nuclear membrane was in good condition. Cell attachment was observed while ER and GB was looking normal. OE was less affected.

At $1 \mathrm{~h}$ of treatment of $A$. conyzoides petroleum ether extract, damage of cell membrane of PL in some parts were noticed but mitochondria was unaffected. Nuclear membrane was damaged and Golgi body was in formative stage. Filopods present and large vesicles in the cytoplasm was observed. GR cell membrane was found totally damaged state and some of the mitochondria was also affected. But nuclear membrane was less affected. ER short and GB was not observed. Attachment of the cells were observed and numerous vesicles were seen. Other cells were less affected. At $12 \mathrm{~h}$ of treatment also, damaged PL cell with ruptured cell membrane, affected mitochondria, large vesicles and filopod were recorded. GR cell was also affected with mitochondrial damage, cell membrane rupture, heavy vacuolization. Release of cytoplasmic material to outside of the cell and import of material was noticed.

At $1 \mathrm{~h}$ of acetone treatment as control almost intact cell membrane, mitochondria, ER, nuclear membrane was observed. Cell attachment was less with few filopods in PL cell. Granules and vesicles number were less and release of cytoplasmic material were not observed in PL cell. But GR cell was affected and plasma membrane rupture and damage in mitochondria was observed. Plenty number of ER but few vesicles were observed. Both types of granules structured and electron dense were observed. Cell aggregation with release of flocculent material was noticed. OE was less affected than PL and GR. But at $6 \mathrm{~h}$ of acetone treatment PL and GR were found intact with intact plasma membrane, nuclear membrane, normal mitochondria, few vesicles and very less cell attachment. A medium 
number of filopods were observed but release of cytoplasmic material was not observed. OE cell was also found intact with unaffected mitochondria. After $48 \mathrm{~h}$ treatment of acetone also, the nuclear membrane and mitochondria of both PL and GR were found intact with less cell attachment. Cell membrane damage of PL was less. Golgi body was found in formative phase and few number of filopods and vesicles were observed but release of flocculent material was not recorded. Nuclear division of PL cell was observed. Cell membrane rupture of some of the GR cell was recorded with discharge of granule while other cells were intact with almost absence of filopods. Plenty number of ER and large sized vesicles were seen. Both types of granules structured and electron dense were noticed.

A comparative assessment of the effects made showed that the rupture of plasma membrane (PM) in plasmatocyte (PLs) was maximum in treatment with A. conyzoides while it was comparatively less in treatment with Ocimum sanctum. Symptoms of immune response i.e. cell attachment between PLs and GRs and among the plasmatocytes along with release of cytoplasmic and granular material from granulocytes were observed in case of treatment with all the plant extracts. Toxic symptoms like highly affected mitochondria with break down of nuclear membrane, dissolution of cristae became evident in case of treatment with A. conyzoides. In case of treatment with Ocimum sanctum the affects were comparatively less and at $48 \mathrm{~h}$ the PLs were exactly similar with those of control insects. Similar effects on ultrastructure PLs and GRs were reported to be caused in lepidopteran insect by neem gold $[95,96]$. Plant based pesticides were earlier reported to decrease prohaemocyte, plasmatocyte and spherulocyte and increase granunlocyte and oenocyte population [95,97]. Gupta(1998) reported on involvement of plasmatocytes and granulocyte in cell mediated immune response. In our investigation also cell lysis, release of granular material, vacuolization and clumping of PLs and GRs were observed after treatment with the plant extracts.

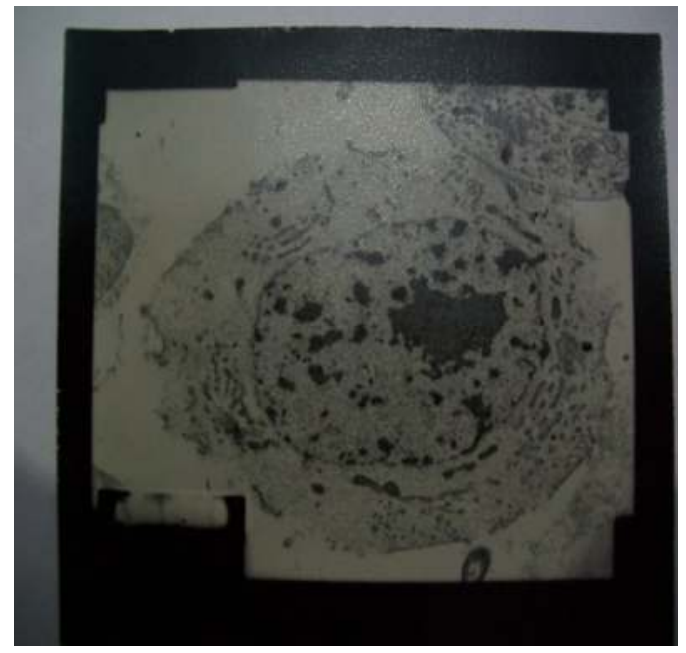

Plate 10. Plasmamembrane rupture in A.conyzoides PL under TEM 


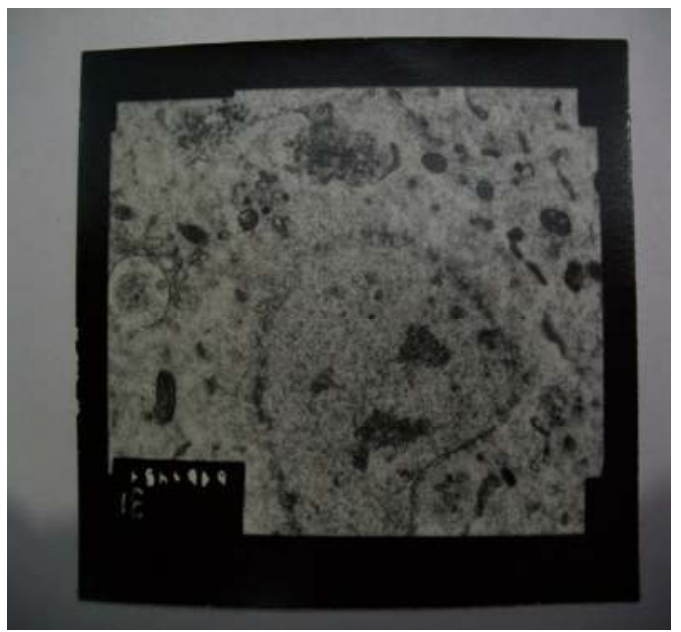

Plate 11. Nuclear membrane rupture A. conyzoides treated PL under TEM

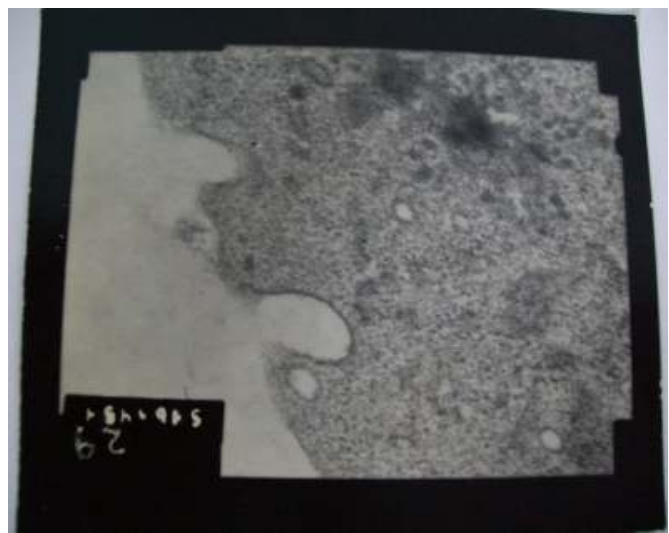

Plate 12. Pinocytic vesicle formation of PL at $12 \mathrm{~h}$ of treatment with $A$. conyzoides

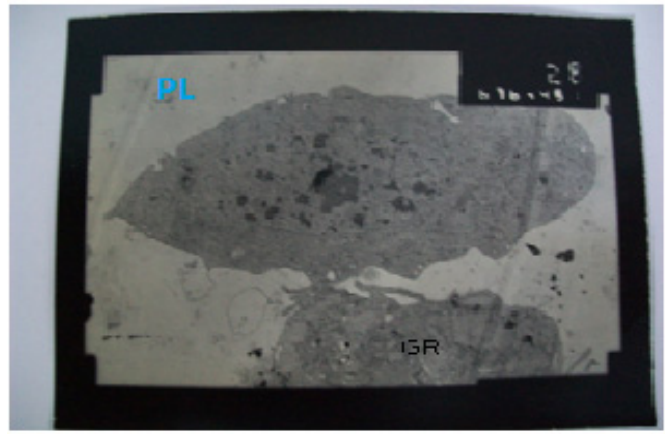

Plate 13. Cell clumping between PLs and GRs at12 h of treatment with A. conyzoides 


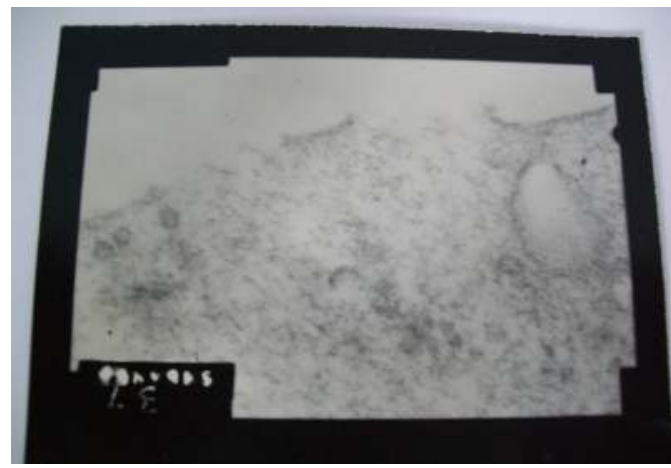

Plate 14. PM rupture at $12 \mathrm{hr}$ after treatment with $O$. sanctum

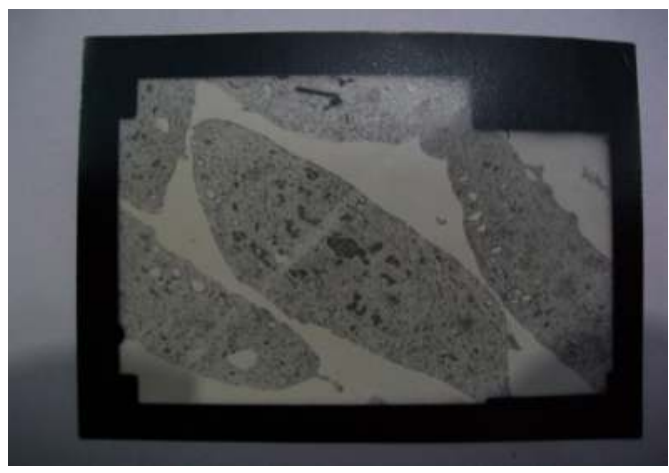

Plate 15. Normal PLs at $48 \mathrm{hr}$ of treatment with O. sanctum under TEM

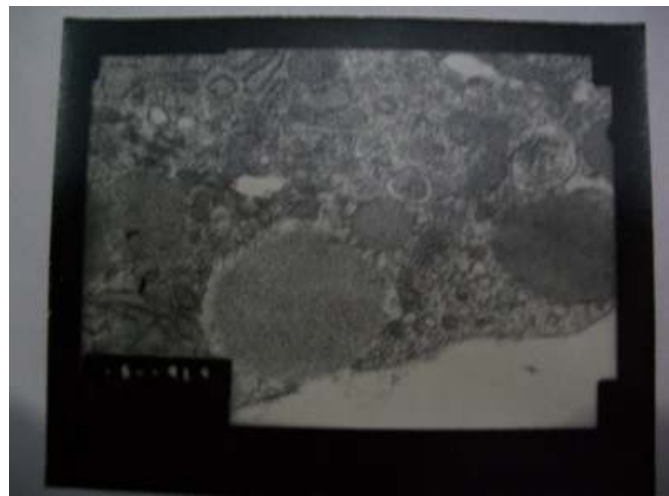

Plate 16. GR at $1 \mathrm{hr}$ of $O$. sanctum treatment under TEM 


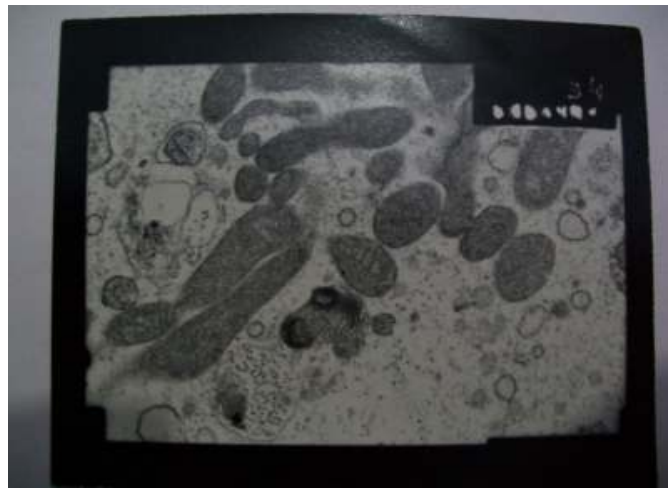

Plate 17. Mitochondria at $15 \mathrm{~min}$ of $O$. sanctum treatment

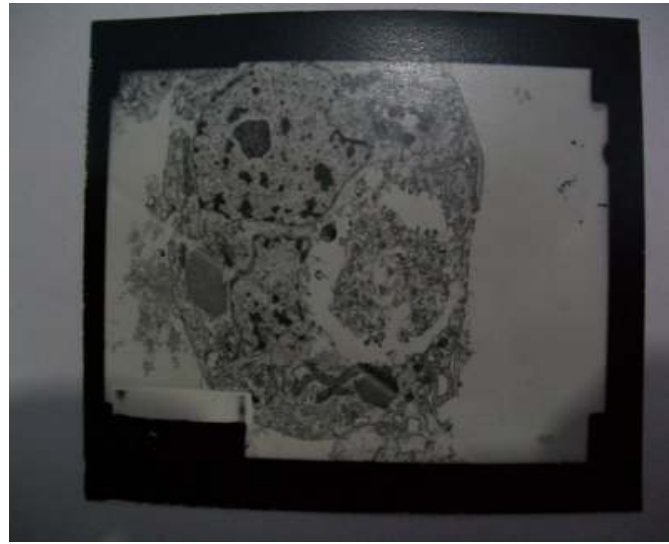

Plate 18. Granulocyte damage at $15 \mathrm{~min}$ of $O$. sanctum

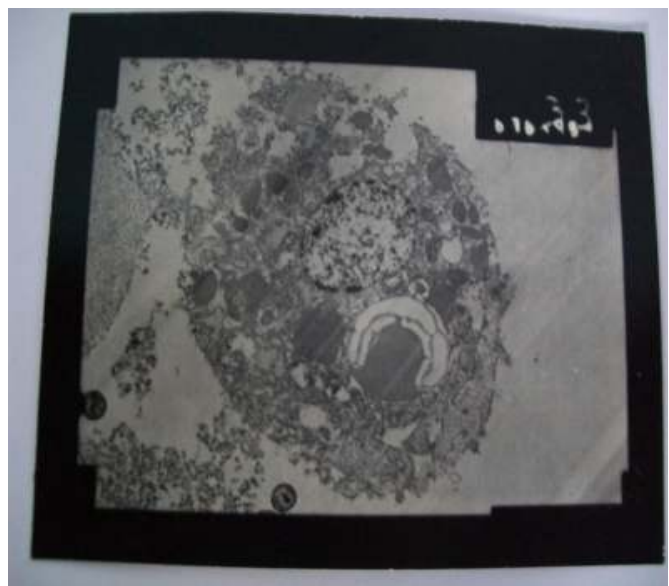

Plate 19. Granular material release at $12 \mathrm{hr}$ of treatment in $O$. sanctum 


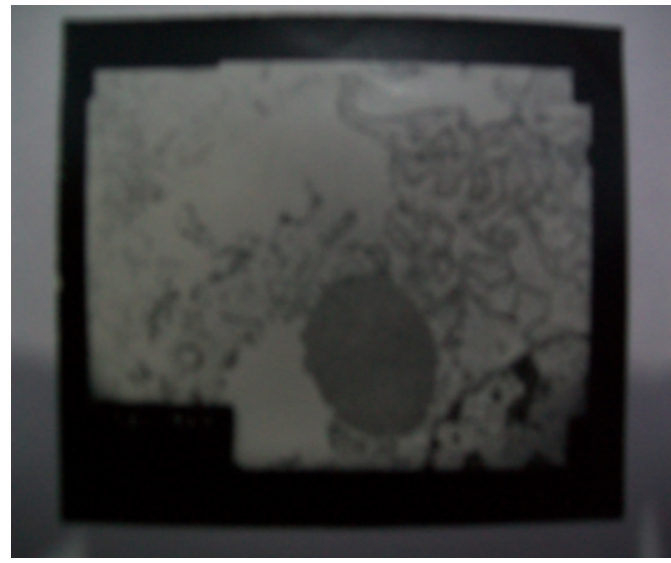

Plate 20. GR breakdown at 1 hr of treatment in A. conyzoides A. conyzoides under TEM

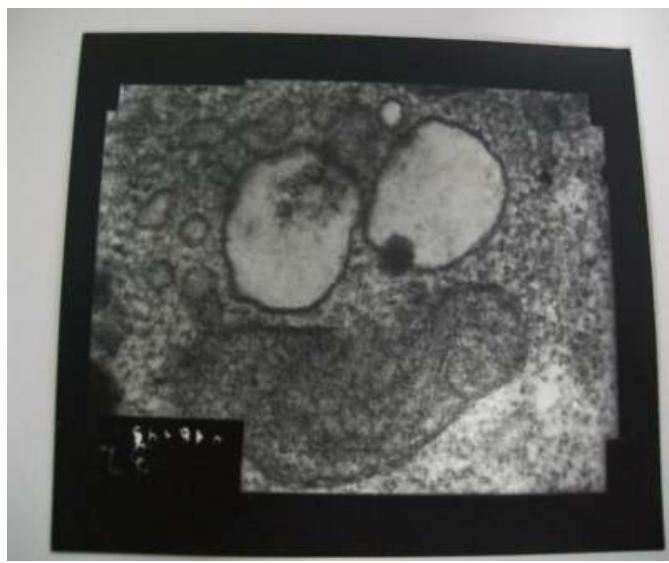

Plate 21. GR mitochondria damage at $12 \mathrm{hr}$ of treatment in A. conyzoides

\subsection{Effect of essential oil on economic characters of silk wrom}

Study on impact of essential oils of $O$. sanctum and $A$. conyzoides after topical application at the dosages of $0.2,0.1,0.02$ and $0.01 \mu \mathrm{lg}^{-1}$ on 2 nd day old $A$. assama fifth instar larvae showed that there was no significant difference on developmental period of fifth instar larvae from that of control in case of treatment of essential oil of O. sanctum. A significant decrease in developmental period was caused by essential oil of $A$. conyzoides at the highest dose. Early spinning of larvae after application of essential oil of $A$. conyzoides might be due to its effect on endocrine system. Precocene found in essential oil of Ageratum species is known to cause precocious metamorphosis through its action on corpora allata [23,99].

Economic characters of silkworm like cocoon weight and pupal weight of treated larvae did not vary significantly from that of control larvae. But significant decrease of shell weight was recorded after application of essential oil of A. conyzoides at all dosages [24]. Reduction in shell 
weight might be due to reduction of spinning period causing precocious metamorphosis which might be caused by precocene II found in A. conyzoides [99]. Thus in comparison to $A$. conyzoides, $O$. sanctum is a preferable candidates for being used against $E$. sorbillan. However, nutritional indices like efficiency of conversion of ingested food into body matter (ECI), efficiency of conversion of digested food into body matter (ECD), approximate digestibility $(\mathrm{AD})$, consumption index $(\mathrm{CI})$, relative growth rate (RGR) were not found to differ significantly from that of control at lower dosages $(0.02,0.01 \mu \mathrm{l} / \mathrm{g})$ after treatment of both essential oils of $O$. sanctum and A.conyzoides [24]. There are also reports stating beneficial effects of plant products on silk worms which is supportive of use of plant products in sericulture field. Botanicals like Curcuma longa, Phyllanthus ambilica, Asparagus racemosus, Aegle marmelos, Boerhavia diffusa, Allium sativum and Ocimum basilicum applied against flacherie infested Bombyx mori larvae increased larval weight, cocoon weight, shell weight, silk ratio [100]. Similar studies on beneficial effects of plant products on growth, development and economic characters of silk worms have been carried out by several workers [101-103]. Synergistic actions of plant chemicals might be responsible for growth enhancement of certain insects [104].

\begin{tabular}{|c|c|c|c|c|}
\hline \multicolumn{5}{|c|}{$\begin{array}{l}\text { Table: Variation of cocoon weight of } A \text {.assama late instar larvae after treatment } \\
\text { with essential oil of plants }(\mathrm{P}<0.05) \text {. }\end{array}$} \\
\hline Dose $\rightarrow$ & $0.2 \mu \mathrm{l} / \mathrm{g}$ & $0.1 \mu \mathrm{l} / \mathrm{g}$ & $0.02 \mu \mathrm{l} / \mathrm{g}$ & $0.01 \mu \mathrm{l} / \mathrm{g}$ \\
\hline Plant(oil) $\downarrow$ & \multirow{4}{*}{$\begin{array}{l}\text { Cocoon weight } \\
(\text { Mean } \pm \text { SE) } \\
5.15 \pm .45 \\
4.81 \pm .31 \\
5.15 \pm .66\end{array}$} & \multirow{4}{*}{$\begin{array}{l}\text { Cocoon weight } \\
(\text { Mean } \pm \text { SE) } \\
4.85 \pm .44 \\
5.30 \pm .29 \\
5.15 \pm .66\end{array}$} & \multirow{4}{*}{$\begin{array}{l}\text { Cocoon weight } \\
\text { (Mean } \pm \text { SE) } \\
5.13 \pm .44 \\
4.81 \pm .31 \\
5.15 \pm .66\end{array}$} & \multirow{4}{*}{$\begin{array}{l}\text { Cocoon weight } \\
\text { (Mean } \pm \text { SE) } \\
4.85 \pm .44 \\
5.3 \pm .29 \\
5.15 \pm .66\end{array}$} \\
\hline O.sanctum & & & & \\
\hline A.conyzoides & & & & \\
\hline Con & & & & \\
\hline \multicolumn{5}{|c|}{$\begin{array}{l}\text { Table: Variation of pupa weight of } A . \text { assama late instar larvae after treatment with } \\
\text { essential oil of plants }(\mathrm{P}<0.05) \text {. }\end{array}$} \\
\hline Dose $\rightarrow$ & $0.2 \mu \mathrm{l} / \mathrm{g}$ & $0.1 \mu \mathrm{l} / \mathrm{g}$ & $0.02 \mu \mathrm{l} / \mathrm{g}$ & $0.01 \mu \mathrm{l} / \mathrm{g}$ \\
\hline Plan & $\begin{array}{l}\text { Pupal weight } \\
\text { (Mean } \pm \text { SE) }\end{array}$ & $\begin{array}{l}\text { Pupal weight } \\
\text { (Mean } \pm \text { SE }\end{array}$ & $\begin{array}{l}\text { Pupal weight } \\
\text { (Mean } \pm \text { SE }\end{array}$ & $\begin{array}{l}\text { Pupal weight } \\
\text { (Mean } \pm \text { SE }\end{array}$ \\
\hline O.sa & \pm 0 & $4.47 \pm 0$. & & \\
\hline oides & \pm 0 & $4.96 \pm 0$. & & \\
\hline Control & $4.75 \pm 0.64$ & $4.75 \pm 0.64$ & $4.75 \pm 0.64$ & \\
\hline \multicolumn{5}{|c|}{$\begin{array}{l}\text { T able: Variation of shell weight of } A \text {.assama a fter treatment with essential oil of } \\
\text { plants }(\mathrm{P}<0.05) \text {. }\end{array}$} \\
\hline Dose $\rightarrow$ & $0.2 \mu \mathrm{l} / \mathrm{g}$ & $0.1 \mu \mathrm{l} / \mathrm{g}$ & $0.02 \mu \mathrm{l} / \mathrm{g}$ & $0.01 \mu \mathrm{l} / \mathrm{g}$ \\
\hline Plant(oil) $\downarrow$ & $\begin{array}{l}\text { Shell weight } \\
(\text { Mean } \pm \text { SE) }\end{array}$ & $\begin{array}{l}\text { Shell weight } \\
(\text { Mean } \pm \text { SE) }\end{array}$ & $\begin{array}{l}\text { Shell weight } \\
(\text { Mean } \pm \text { SE) }\end{array}$ & $\begin{array}{l}\text { Shell weight } \\
(\text { Mean } \pm \text { SE) }\end{array}$ \\
\hline O.sa & $0.34 \pm 0.01$ & $0.34 \pm 0.04$ & 0.3 & .04 \\
\hline coides & $0.26 \pm 0.04$ & $0.29 \pm 0.02$ & 0.01 & 0.2 \\
\hline Control & $0.32 \pm 0.02$ & $0.32 \pm 0.02$ & $0.32 \pm 0.02$ & $0.32 \pm 0.02$ \\
\hline \multicolumn{5}{|c|}{$\begin{array}{l}\text { Table: Variation of developmental period after treatment with essential oil of } \\
\text { plants }(P<0.05) \text {. }\end{array}$} \\
\hline Dose $\rightarrow$ & $0.2 \mu \mathrm{l} / \mathrm{g}$ & $0.1 \mu \mathrm{l} / \mathrm{g}$ & $0.02 \mu \mathrm{l} / \mathrm{g}$ & $0.01 \mu \mathrm{l} / \mathrm{g}$ \\
\hline Plant(oil) $\downarrow$ & $\begin{array}{l}\text { Dev period } \\
(\text { Mean } \pm \text { SE })\end{array}$ & $\begin{array}{l}\text { Dev period } \\
(\text { Mean } \pm \text { SE })\end{array}$ & $\begin{array}{l}\text { Dev period } \\
(\text { Mean } \pm \text { SE) }\end{array}$ & $\begin{array}{l}\text { Dev period } \\
(\text { Mean } \pm \text { SE })\end{array}$ \\
\hline O.sat & $11.67 \pm .33$ & $11.67 \pm .33$ & $11.33 \pm .33$ & $11.67 \pm .33$ \\
\hline A.conyzoides & $10 \pm 0$ * & $10.67 \pm .33$ * & $11.00 \pm .58$ * & $11.67 \pm .33$ \\
\hline Control & $11.67 \pm .33$ & $11.67 \pm .33$ & $11.67 \pm .33$ & $11.67 \pm .33$ \\
\hline
\end{tabular}

$\mathrm{SE} \rightarrow$ Standard error $^{*} \rightarrow$ significant at $95 \%$ Confidence Interval

Table 4. Variation of cocoon weight of A. assama late instar larvae after treatment with essential oil of selected plants $(\mathrm{P}<0.05)$ 


\section{Mechanism of action of botanicals}

The efficacy of plant products depend on presence of specific organic compound (s) which may interfere with the body physiology of the target organism. The compounds may belong to different chemical groups of secondary metabolites of plants viz. Alkaloids, phenolics, flavonoids and terpenoids. The ethanolic extract of $O$. sanctum is reported to have greater and broader spectrum of activity against tested organisms [106]. Literature reveals that in comparison to essential oil less works have been carried out to isolate and characterize bioactive compound of Ocimum sp. having insecticidal potency through solvent extraction and hence knowledge regarding the use of solvent extracts of Ocimum is comparatively less. Petroleum ether and acetone extract of $A$. conyzoides earlier was reported to have juvenile hormone activity against Culex quinqufasciatus, Aedes aegpti and Aedes stephensi. Hexane extract was found effective against Musca domestica and methanolic extract caused abnormal development and suppression of population of Anopheles stephensi [99,106,107]. Thiophene derivative, a class of compound found in many Asteraceae species has been attributed for the toxic effect of the plant. The hexane fraction of acetone extract of $C$. roseus containing alphaamyrin is postulated to be active IGR against many pests [63]. Moreira et al. [107] showed the hexane extract of Ageratum conyzoides to have insecticidal activity and purified the compounds using IR, 1H NMR, 13 c NMR, HMBC. The compounds were5,6,7,8,3/,4/,5/ heptamethoxy flavone, 5,6,7,8,3/ pentamethoxy-4/,5/-methylene dioxyflavone and coumarin out of which only coumarin showed insecticidal activity against dictyopteran, lepidopteran and dipteran.

The mechanism of toxic effect of essential oil and oil compounds on insect at present is not well known. Insects vary enormously in their response to different essential oils and oil compounds. Essential oils are liquid in room temperature and get easily transformed from a liquid to a gaseous state at room or slightly higher temperature without undergoing decomposition. The quantity of essential oil found in most plants is 1 to $2 \%$ but can contain amounts ranging from 0.01 to $10 \%$. Most essential oils comprise of monoterpenes with 10 carbon atoms, sesuiterpenes with 15 carbon atoms and rarely diterpenes or higher terpenes. The most predominant groups are cyclic compounds with saturated and unsaturated hexacyclic or an aromatic system. Bicyclic and acyclic components are also present[2]. Monoterpenes are common essential oil constituents and several hundred naturally occurring monoerpenes are reported. They are biosynthesized from geranyl pyrophosphate of the isoprenoid pathway. These can be classified into two major groups- monoterpene hydrocarbons and oxygenated monoterpenes. Monoterpene hydrocarbons include acyclic aliphatic, monocyclic aliphatic and dicyclic aliphatic while oxygenated monoterpenes include acyclic monoterpenoid, monocycic monoterpenoid and dicyclic monoterpenoids [41]. Some of the major oil constituents of $O$. sanctum are methyl eugenol, caryophyllene, germacrene D, $\beta$-elemene, eugenol, caryophyllene epoxide and $\alpha$-cadinol [24,108,109]. Oil of A. conyzoides plant collected from South-East Asian countries mostly contains sesquiterpene Beta-caryophyllene, demethoxyageratochromene and many monoterpenes [ 24,110]. The monoterpenes in Indian oil of $A$. conyzoides have been reported to be mainly Ocimene (5.3\%), alpha-pinene (6.6\%), eugenol (4.4\%), methyl eugenol (1.8\%) and the sesquiterpenes are Betacaryophyllene $(1.9 \%)$, Delta- cadinene $(4.3 \%)$, sesquiphellandrene $(1.2 \%)$ and caryophyllene 
epoxide (0.5\%) [62]. Eugenol was earlier reported to be effective against mosquitoes in Michigan [60]. Compounds like coumarin and mainly furanocoumarins can alter the detoxication capability of an organism by reversibly or irreversibly inhibiting cytochrome P450 detoxication enzymes [111-112]. They are also reported to have neurotoxic mode of action probably through binding with different types of octapamine receptors and interference with octapamine activity [113-115] or interference with GABA-gated chloride channels [2,115] or inhibition of achetylcholine esterase [116-118]. Such activity of the oil may be attributed to action of a single major compound or synergistic actions of group of compounds [119].

The root-bark extract of Zanthoxylum nitidum having efficacy against rice pest contains several alkaloids $[120,121]$ out of which benzo[c]phenanthridine alkaloids (sanguinarine and chelerythrine) are reported to have the molluscicidal activity [122]. Alkaloid is a large group of plant secondary metabolites and its occurrence has been reported in approximately $20 \%$ of all plant species. Most of the alkaloids exert their effect on different region of the nervous system. Different neuroreceptors like alpha, serotonin, muscarinic, nicotinic acetylcholine receptors, adrenergic receptor and enzymes involved in synaptic transmission are some of the target sites of alkaloids. Basic molecular targets are DNA intercalation, protein biosynthesis and membrane stability [123].

The structures of phenolic allelochemicals and their mode of action are diverse [124]. In lepidopteran larvae, phenolic toxicity might occur in the form of oxidative stress [125]. However, Heliothis virescens larvae after feeding with high phenolic foliage exhibited improved total Trolox equivalent antioxidant capacity (TEAC) in haemolymph [126]. Therefore it has been proposed that the elevated foliar phenolics in some plants might have beneficial antioxidant properties for herbivorous insects. Flavonoids are known to inhibit cholinesterases [127] and might be responsible for insecticidal action [128]. Various forms of saponins and sterols derived from different plants have been reported to act as insect growth regulator [129].

\section{The future of prospects of botanicals in seri-ecosystem}

An important essence of integrated pest management is to consider the whole ecosystem as the management unit. A seri-ecosystem should necessarily include not only the sericulture field or the silkworm culture units, but also the agricultural field in the neighbouring areas. A consensus approach is to keep the natural ecosystem largely intact. While attempts are made to control pests and pathogens in the neighbouring agricultural fields, issues regarding their impact on sericulture activities must be taken into consideration or viceversa. Emphasis is to be given on studies associated with efficacy of plant and plant products against pests and pathogens in the whole management unit, their mode and mechanism of action, identification of target sites and use of resistant strains. Life scientist and chemist need to act coherently to make effective use of botanicals. With the knowledge in hand we hypothesize that holistic approach involving in depth research for using botanical in both sericulture field and the other crop systems in the vicinity might be able to provide a green environment to the silk worms. 


\section{Author details}

Dipsikha Bora and Hiren Gogoi

Department of Life Sciences, Dibrugarh University, Dibrugarh, Assam, India

Bulbuli Khanikor

Department of Zoology, Gauhati University, Guwahati, Assam, India

\section{Acknowledgement}

The authors are grateful to UGC, India for funding part of the work. Thanks to Mr. B.Deka for helping in statistical analysis.

\section{References}

[1] Carson R (1962) The Silent spring. Houghton Mifflin. US.

[2] Koul O, Walia S, Dhaliwal GS (2008) Essential oils as green pesticides: potential and constraints. Biopesticides Int. 4(1): 63-84.

[3] Afshan I, Murthy DS (2005) Price transmission in silk industry of Karnataka. In: Conference Papers-The $20^{\text {th }}$ Congress of the International Sericultural Commission.3 (6):257-261.

[4] Teotia RS, Sen SK (1994) Mulberry disease in India and their control. Sericologia. 34: 1-18.

[5] Datta SC, Datta R (2007) Increased silk production by effective treatment of naturally infected root-knot and black leaf spot diseases of mulberry with acaciasides. Journal of Environmental \& Sociobiology. 4: 209-214.

[6] Bora DS (1998) Effect of environmental stress with special reference to photoperiod and insecticide on muga worms. Antheraea assama Westwood. Ph.D. Thesis, Dibrugarh University, Dibrugarh, Assam, India.

[7] Li B, Wang Y, Liu H, Xu Y, Wei Z, Chen Y, Shen W (2010) Resistance comparison of domesticated silkworm (Bombyx mori L.) and wild silkworm (Bombyx mandariana M.) to phoxim insecticide. African Journal of Biotechnology. 9(12):1771-1775.

[8] Wiayanthi N, Subramanyam MV (2002) Effect of fenvalerate-20EC on sericigenous insects. I. Food utilization in the late-age larva of the silkworm, Bombyx mori L. Ecotoxicol Environ Saf. 53(2):206-211.

[9] Bhagyalakshmi A, Venkata RS, Ramamuthi R, Reddy PS (1995) Studies on the effect of hexachlorocyclohexane on the growth and silk qualities of silkworm, Bombyx mori L. Chemistry and Ecology. 11(2):97-104.

[10] Naik PK, Delvi MR (1984) Effects of insecticide, permethrin, on dietary water utilization in eri-silkworm Philosamia ricini. Proc. Indian Acad. Sci. (Animal Sci.). 93(5): 497-504.

[11] Wilkinson CF (1976) Insecticide Biochemistry and Physiology. Plenum Press. New York.

[12] Zabik MJ (1985) Photochemistry of pesticides. In: Comprehensive Insect Physiology, Biochemistry and Pharmacology. Gilbert LI and Kerkut GA editors. Pergamon Press, Oxford. 12 : 776-801 
[13] Chukudebe A, March RB, Othman M, Fukuto TR (1989) Formation of trialkyl phosphorothioate esters from organophosphorus insecticides after exposure to either ultraviolet light or sunlight. J. Agric. Food. Chem. 37(2): 539-545.

[14] Haynes KF (1988) Sublethal effects of neurotoxic insecticides on insect behaviour. Ann. Rev. of Entomology. 33: 149-168.

[15] Kariappa BK, Narasimhanna MN (1978) Effect of insecticides in controlling mulberry thrips and their effect on rearing silk worm Bombyx mori L. Indian J. Seric. 17: 7-14.

[16] Troitskaya EN, Chichigina IP (1980) The effect of combined insecticidal preparations on silkworm larvae. Uzbekshii Biologicheskii Zhurnal. (3): 50-53.

[17] Waldbauer GP (1968) The consumption and utilization of food by insects.Adv. Insect Physiol. 5: 233-282.

[18] Tazima Y (1978) The Silkworm: an important laboratory tool. Kodansha Ltd.

[19] Yu QU, Lu C, Li WL, Xiang ZH, Zhang Z (2009) Annotation and expression of carboxylesterases in the silkworm, Bombyx mori. BMC Genomics. 10:553 doi:10.1186/1471-2164-10-553.

[20] Toutant JP (1989) Insect acetylcholinesterase: catalytic properties, tissue distribution and molecular forms. Prog Neurobiol. 32:423-446.

[21] Oakeshott JG, Claudianos C, Campbell, PM, Newcomb RD, Russell RJ (2005) Biochemical genetics and genomics of insect esterases. In :Comprehensive molecular insect science. Gilbert LI, Iatrou K, Gill SS editors. London: Elsevier. 5: 309-361.

[22] Shang JY, Shao YM, Lan GJ, Yuan G, Tang ZH, Zhang CX (2007) Expression of two types of acetylcholinesterase gene from the silkworm, Bombyx mori, in insect cells. Insect Sci. 14:443-449.

[23] Pedigo LP (2002) Entomology and Pest Management. Pearson Education Inc.

[24] Khanikor B (2011) Evaluation of extracts and essential oils of Ocimum and Ageratum against uzi fly, Exorista sorbillans (Wiedemann), a parasitoid of Antheraea assama Westwood. Ph.D. Thesis. Dibrugarh University. Dibrugarh. India.

[25] Nath BS, Suresh A, Verma BM, Kumar RPS (1997) Changes in protein metabolism in haemolymph and fat body of the silk worm, Bombyx mori (Lepidoptera : Bombycidae) in response to OP insecticidal toxicity. Ecotoxicology and Environmental safety.36 (2):169173.

[26] Burt PE, Lord KA (1977) In: Biochemical Insect Control. Quarshi S. Wiley Interscience Publication, New York.183.

[27] Morgan DP, Roan, CC, Paschal EH (1976) In : Toxicology of insecticides. Matsumura F. editor. Plenum Press, New York.

[28] Burt PE, Lord KA, Forrest JM, Goodchild RE (1971) The spread of topically applied pyrethrin-I from the cuticle to the central nervous system of cockroach, Periplaneta Americana. Entomol. Exp. Appl. 14 : 255-269.

[29] Morairity F, French MC (1971) The uptake of dieldrin from the cuticular surface of Periplaneta amaricana L. Pesticide Biochemistry Physiology. 19: 286-292.

[30] Saxena PN (1990) Organophosphate intoxication in insect body: penetration, kinetics and target site interaction In : Environmental impact on Biosystems. Dalela RC editor. Academy Environmental Biology, India. 47-67. 
[31] Bora D and Handique R (1996) Insecticide induced biochemical changes in Antheraea assama Westwood. Proc. Acad. Environ. Biol. 5(2):221-226.

[32] Tiwari SK, Bhatt RS (1996) Methoxychlor and dimethoate induced changes in biochemical components in the haemolymph and fatbody of the larva of rice moth, Corcyra cephalonica Staint.(Lepidoptera:Pyralidae). Uttar Pradesh J. Zool. 16 (1):1-8.

[33] Patel IS, Yadav DN, Shukla YM (1996) Biocemical basis of mechanism in a monocrothphos resistant strain of the predator, Green lace wing, Chrysopa scelestes Banks. Annal. Plant Protec. Sci. India. 66 (B): 2.

[34] Handique R, Bora D, Chetia P, Kotoky D (2002) Effect of diesel exhaust on cholesterol uptake by muga silkworms. Indian J. Sericulture. 41(1): 29-33.

[35] Bora D, Handique R (1992) Effect of several synthetic insecticides on growth, development, food consumption and food utilization of Antheraea assama Westwood larvae. Proc. Acad. Environ. Biol. 1(2): 195-203.

[36] Swain T (1977) Secondary compounds as protective agents. Annu. Rev. Plant. Physiol. 28: 479- 501.

[37] Rosenthal GA,Janzen D (1979) Herbivores: Their interaction with secondary plant metabolites. NY: Academic.718

[38] Dethier VG (1982) Mechanism of host plant recognition. Ent exp appl Ned Entoml Ver Amsterdam. 31:49-56.

[39] Balandrin MF (1985) Natural Plant Chemicals: Sources of Industrial and Medicinal Materials. Science. 228: 1154-1160.

[40] Sukumar K, Perich MJ, Boobar LR (1991) Botanical derivatives in mosquito control: A review. J. Amer. Mosq. Control Ass. 7: 210-237.

[41] Harborne JB(1998) Phytochemical Methods. A guide to modern techniques of plant analysis, Third Edition. Chapman and Hall, London. 302.

[42] Mishra AK, Dubey NK (1994) Evaluation of some essential oils for their toxicity against fungi causing deterioration of stored food commodities. Applied and Environmental Microbiology. 60: 1101-1105.

[43] Subramanyam B, Roesli R (2000) Inert dusts. In: Alternatives to Pesticides in StoredProduct IPM, Subramanyam BH and Hagstrum DW editors. Kluwer Academic Publishers, Dordrecht. 321-380.

[44] Rawls RL (1986) Experts Probe Issuses, Chemistry of light activated pesticides. Chem. Eng. News. Sept. 22: 2124.

[45] Yadav D (2011) Bio-pesticides and bio-fertilizer for sustainable sericulture. The Silkworm. 28 ${ }^{\text {th }}$ August.

[46] Dura VK, Nagpal BN, Sharma VP (1995) Repellent action of Neem cream against mosquitoes. Indian J. Malariol. 32: 47-53.

[47] Nagpal BN, Srivastava A, Sharma VP (1996) Control of mosquito breeding using scrapings treated with Neem Oil. Indian J. Malariol. 32: 64-69.

[48] Kumar GS (2012) Experimental study to find the effect of different neem (Azadirachta indica) based products against moringa hairy caterpillar (Eupterotemollifera Walker). International journal of Biology, Pharmacy and Allied sciences. 1(1): 22-28. 
[49] Sathyaseelan V, Bhaskaran V (2010) Efficacy of some native botanical extracts on the repellency property against the pink mealy bug, Maconellicoccus hirsutus (green) in mulberry crop. Recent Research in Science and Technology. 2(10): 35-38.

[50] Isaiarasu L, Sakthivel N, Ravikumar J, Samuthiravelu P (1969) Effect of herbal extracts on the microbial pathogens causing flacherie and muscardine diseases in the mulberry silkworm, Bombyx mori L. Journal of Biopesticides. 4 (2): 150-155.

[51] Kumar KPK, Singh GP, Sinha AK, Madhusudhan KN, Prasad BC (2012) Antibacterial action of certain medicinal plants against AmCPV and their effect on cellular and biochemical changes in tasar silkworm, Antheraea mylitta D. Research Journal of Medicinal Plants. 6(1):92-99.

[52] Unni B, Dowarah P, Wann S and Gangadharrao A (2011) Muga heal- Terminalia chebula based bioformulation as an antiflacherie agent and a silk fiber enhancer. Science and Culture. 456-460.

[53] Woytek R (1998) Indigenous knowledge for development: a framework for development. Knowledge and Learning Centre, Africa Region, World Bank.

[54] Amaugo GO, Emosairue SO (2003) The efficacy of some indigenous medicinal plant extracts for the control of upland rice stem borers in Nigeria. Tropical and subtropical agroecosystems. 2: 121-127.

[55] O'Hara J (1992) Exorista sorbillans-a serious tachinid pest of silkworms. The Tachinid Times: 51-17.

[56] Sahu M, Sahu AK and Bindroo BB (2008) Biological control of uzi fly Infestation in Muga. Indian silk.46 (10):18-19.

[57] Bora DS, Khanikor B, Konwar M (2010) Plant extracts for management of UZI fly Exorista sorbillans Wiedemann (Diptera: Tachinidae). In: Bioresources For Rural Livelihood. Kulkarni GK, Pandey BN and Joshi BD, editors. Narendra Publishing House. New Delhi, India. 217-224.

[58] Obeng-Ofori D, Reichmuth C (1997) Bioactivity of eugenol, a major component of essential oil of Ocimum suave (Wild) against four species of store product Coleoptera. Intl. J. of Pest Manag.43(1):89-94.

[59] Kelm MA, Nair MG (1998) Mosquitocidal compounds and a triglyceride, 1, 3dilinoleneoyl-2-palmitin from Ocimum sanctum. J. Ag. Food Chem. 46:3092-3094.

[60] Kelm MA (1999) Bioactive compounds from Ocimum sanctum Linn. Lamiaceae. Ph.D.Thesis, Michigan State University. 95.

[61] Kamaraj C, Rahuman AA, Bagavan A, Zahir AA, Elango G, Kandan P, Rajakumar G, Marimuthu S, Santhoshkumar T (2010) Larvicidal efficacy of medicinal plant extracts against Anopheles stephensi and Culex quinquefasciatus (Diptera: Culicidae). Tropical Biomedicine. 27(2): 211-219.

[62] Okunade AL (2002) Ageratum conyzoidesL.(Asteraceae). Fitotherapia 73:1-16

[63] Brun G, Bessiere JM, Dijoux FMG, David B, Mariotte AM (2001) Volatile components of Catheranthus roseus(L.) G.Don (Apocynaceae). Flavour and Fragrance Journal. 16(2):116-119

[64] Gogoi H, Bora DS (2012) Bio-efficacy of extracts of some plants of ethnic importance against Nymphula depunctalis Guenee (Lepidoptera:Pyralidae).North Bengal University Journal of Animal Sciences.(Press). 
[65] Shroff KD (1920) Notes on miscellaneous pests of Burma. In Proceedings of the Third Entomological Meeting, Dept. Agric. Calcutta.Pusa, India. 351-353.

[66] Sison P (1938) Some observations in the life history, habits and control of the rice caseworm Nymphula depunctalis Guenee. Philipp. J. Agric. 9: 273 - 301.

[67] Alum AZ (1967) Insect pest of rice in East Pakistan. John Hopkins press. 633-655.

[68] Grist DH, Lever RJAW (1969) Pest of rice. Longmans, Greens \& Co. Ltd.London

[69] Chi TTN, Tam BTT, Dau HX, Khoa, NT, Lan NTP, Paris TR (1995) Current status of rice pest management by farmers in direct-seeded rice and transplanted rice area. Omonrice. 4: 42-50.

[70] Vromant N, Rothuis AJ, Cuc NTT, Ollevier F (1998) The effect of fish on the abundance of rice caseworm Nymphula depunctalis (Guenee) (Lepidoptera: Pyralidae) in directseeded, concurrent rice-fish fields. Biocontrol Science and Technology. 8: 539-546.

[71] Patgiri P (1997) Bioecological studies of Nymphula depunctalis (Guenee) (Pyralidae: Lepidoptera) and its management. Dissertation, Ph.D. Assam Agricultural University, Jorhat, India.

[72] Pathak, MD (1975) Insect pests of rice. Manila (Philippines): International Rice Research Institute.

[73] Reissig WH, Heinrichs EA, Litsinger JA, Moody K, Fiedler L, Mew TW, Barrion AT (1985) Illustrated guide to integrated pest management in rice in tropical Asia. Los Banos, the Philippines: IRRI.411.

[74] Hill DS (1987) Agricultural insect pests of the tropics and their control (2 ${ }^{\text {nd }}$ ed.). Cambridge University Press, Cambridge.

[75] Lefroy HM (1908) Indian insect life. Jhacker and Co. Creed Lane, London. 516.

[76] Ghosh RLM, Ghatge MB, Subramanayan V (1956) Rice in India. ICAR publication. New Delhi.

[77] Joseph KV (1969) Incidence of rice caseworm Nymphula depunctalis (Guenee) as a major pest in Kerela. J. Bombay Nat. Hist. Soc. 66: 395-396.

[78] Prakashrao PS, Padhi G (1984) Varietal susceptibility to rice caseworm Nymphula depunctalis Guenee and its behaviour. Oryza 21: 157-162.

[79] Haq M, Haque NMM, Karim ANMR (2006) Incidence pattern of rice caseworm (Nymphula sp). J. Agric. Rural Dev. 4 (1 \& 2): 7-81.

[80] Heinrichs E.A., Viajante V.D. 1987. Yield loss in rice caused by the rice caseworm Nymphula depunctalis (Guenee) (Lepidoptera: Pyralidae). Current Science. 47: 928-929.

[81] Busvine JR (1971) A critical review of the techniques for testing insecticides. Commonwealth Agricultural Buereux: London.345

[82] Morse JG, Bellows TS, Iwata Y(1986) Technique for evaluating residual toxicity of pesticides to motile insects. J. Econ. Entomol. 79(1): 281 - 283.

[83] Hazarika LK, Bhuyan M, Hazarika BN (2009) Insect pests of tea and their management. Annual Review of Entomology. 54 : 267-284.

[84] Deka MK, Singh K and Handique R (1999) Antifeedant and oviposition deterrent effect of Melia azadirach L. and Adhatoda vasica L. against tea mosquito bug. Annal. Of Plant Protec. 7(1):26-29. 
[85] Patil GS, Patil MG, Mendki PS, Maheswari VL, Kothari RM (2000)Study of antimicrobial and pesticidal activity of Nerium indicum. Pestology. XXIV:5

[86] Rahman I (2010) Insecticidal potential from some locally available plants against bunch caterpillar, Andraca bipunctata Waker.(Lepidoptera: Bombycidae). Bulletin of Life Sciences. $16: 11-17$

[87] Emden HFV (1989) Pest contol. Cambridge University Press. London. 82-105.

[88] Hsin CY, Coats JR (1986) Metabolism of isofenphos in southern corn rootworm. Pesticide Biochemistry and Physiology. 25(3):336-345.

[89] Stenersen J, (2004) Chemical Pesticides- Mode of Action and Toxicology. CRC Press, USA.

[90] Bora DS, Khanikor B (2011) Selective toxicity of Ageratum conyzoides and Ocimum sanctum against Exorista sorbillans (Diptera:Tachinidae) and Antheraea assama (Lepidoptera: Saturniidae). Natl. Acad. Sci. Lett. 34: 9-14.

[91] Lawrence BM (1992) Labiatae oils: mother nature's chemical factor.. Eds. Lawrence BM, editors. Essential oils 1988-1991. Allured Publ. Stream, IL. 188-206.

[92] Grayer RJ, Harborne JB(1994) A survey of antifungal compounds from higher plants 1982-1993. Phytochemistry. 37:19-42.

[93] Vieira RF, Simon JE(2006) Chemical characterization of basil (Ocimum spp.) based on volatile oils. Flavour and Fragrance Journal.21:214-221.

[94] Ananth S, Thangamahi P, Pazhanisami S, Meena S (2009) Larvicidal activity of three medicinal plants against filarial mosquito Culex quinqufasciatus(Say). Journal of Basic and Applied Biolog. 3(1\&2):53-58.

[95] Sharma PR, Sharma OP, Saxena BP (2003) Effect of neem gold on haemocytes of the tobacco armyworm, Spodoptera litura (Fabricius) (Lepidoptera: Noctuidae). Curr.Sci.84 (5):690-695.

[96] Sharma PR, Sharma OP, Saxena BP (2008) Effect of sweet flag rhizome oil (Acorus calamus) on hemogram and ultrastructure of hemocytes of tobacco armyworm, Spodoptera litura (Lepidoptera: Noctuidae). Micron. 39:544-551

[97] Rajkumar JA, Subramaniyam B, Devakumar (2000) Growth regulatory activity of silver fern extract on the cocoon bollworm Helicoverpa armigera (Hubner). Insect Science Appl.20:295-302.

[98] Gupta AP (1991) Insect immunocytes and other hemocytes: roles in cellular and humoral immunity. In: Immunology of Insects and Other Arthropods. Gupta AP, editor. CRC Press. Florida. USA. 119p.

[99] Calle J, Rivera A, Luis JG, Aguiar Z, Nimeyer H M, Nathan PJ (1990) Insecticidal activity of petroleum ether extract of Ageratum conyzoides L. Rev Colomb QUIM.19:91-96.

[100] Pachiappan P, Aruchamy MC, Ramanna SK (2009) Evaluation of antibacterial efficacy of certain botanicals against bacterial pathogen Bacillus sp. of silkworm, Bombyx mori L. Int. J. Indust Entomol. 18(1): 49-52.

[101] Rajasekaragouda R, Gopalan M, Jeyaraj N, Natarajan (1997) Field performance of plant extracts on mulberry silkworm, Bombyx mori L. Entomon. 22 (3 \& 4) : 235 - 238. 
[102] Murugan K, Jeyabalan D, Senthikumar N, Senthilnathan S, Sivaprakasam N (1998) Growth Promoting effect of plant products on silkworm. A Biotechnological Approach. Journal of Scientific and Industrial Research $57: 740$ - 745.

[103] Manimuthu M, Isaiarasu L (2010) Herbal tonic on silkworm Bombyx mori. J. of Biopesticides. 3(3):567-572.

[104] Lawless J, Allen J (2000) Aloe vera - Natural Wonder Cure. Harper Collins Publishers, London.

[105] Mahmood K, Yaqoob U, Bajwa R (2008) Antibacterial activity of essential oil of Ocimum sanctum L. Mycopath. 6:63-65.

[106] Saxena RC, Dixit OP, Sukumaran P (1992) Laboratory assessment of indigenous plant extracts for antijuvenile hormone activity in Culex quinquefasciatum. Indian J Med Res 95:204-206.

[107] Moreira MD, Picanco MC, Barbosa LC, Guedes RNC, Borros EC, Campos MR (2007) Compounds from Ageratum conzyoides: isolation, structural elucidation and insecticidal activity. Pest Management Science. 63(6): 615-621.

[108] Prakash P, Gupta N (2005): Therapeutic uses of Ocimum sanctum Linn (Tulsi) with a note on eugenol and its pharmacological actions: a short review. Ind. J. Physiol. Pharmacol. 49(2):125-131.

[109] Kicel A, Kurowska A, Kalemba D (2005) Composition of essential oil of Ocimum sanctum L. grown in Poland during vegetation. J. of Essential Oil Res. 17(2):217-219.

[110] Rana VS, Blazquez MA (2003) Chemical composition of the volatile oil of Ageratum conyzoides aerial parts. Intl. J.of Aromatherapy. 13(4):203-206.

[111] Neal JJ, Wu D (1994) Inhibition of insect cytochromes P450 by furanocoumarins. Pesticide Biochemistry and Physiology. 50: 43-50.

[112] Enan E (2001) Insecticidal activity of essential oils : octopaminergic sites of action. Comparative Biochemistry and Physiology. 130:325-337.

[113] Kostyukovsky M, Rafaeli A, Gileadi C, Demchenko N, Shaaya E (2002) Activation of octopaminergic receptors by essential oil constituents isolated from aromatic plants: possible mode of action against insect pests. Pest Management Science. 58(11):11011106.

[114] Price DN, Berry MS (2006) Comparison of effects of octopamine and insecticidal essential oils on activity in the nerve cord, foregut, and dorsal unpaired median neurons of cockroaches. J. Insect Physiol. 52(3):309-319.

[115] Priestley CM, EM Williamson, KA Wafford, DB Sattelle (2003) Thymol, a constituent of thyme essential oil, is a positive allosteric modulator of human GABA receptors and a homo-oligomeric GABA receptors from Drosophila melanogaster. Br. J. Pharmacol., 140: 1363-1372.

[116] Ryan MF, Byrne O (1988) Plant insect coevolution and inhibition of acetylcholinesterase. J. of Chem. Ecol.14:1965-1975.

[117] Coats JR, Karr LL, Drewes CD (1991) Toxic and neurotoxic effects of monoterpenoids in insects and earthworms. In: Natural Occuring Pest Bioregulators. Hedin P editor. Am.Chem. Soc. Symposium series. 449:305-316. 
[118] Abdelgaleil SAM, Mohamed MIE, Badawy MEI, El-arami SAA (2009) Fumigant and contact toxicities of monoterpenes to Sitophilus oryzae (L.) and Tribbolium castaneum (Herbst) and their inhibitory effects on acetylcholinesterase activity. J Chem Ecol.35:518-525.

[119] Gallindo LA, Pultrini AM , Costa M (2010) Biological effects of Ocimum gratissimum L. are due to synergic action among multiple compounds present in essential oil. J Nat Med. 64(4):436-441.

[120] Geng D, Li DX, Shi Y, Liang JY, Min ZD (2009) A new Benzophenanthridine alkaloid from Zanthoxylum nitidum. Chinese J. Nat. Med. 7 (4): $274-277$.

[121] Chen JJ, Lin YH, Day SH, Hwang TL, Chen IS (2011) New benzenoids and antiinflammatory constituents from Zanthoxylum nitidum. Food Chemistry. 125 (2): 282-287.

[122] Ming Z, Gui-Yin, Jian-Guo Z, Li Z, Ke-Long H, Jin-Ming S, Xiao L and Wang-Yuan W (2011) Evaluation of molluscicidal activities of benzo[c]phenanthridine alkaloids from Macleaya cordata (Willd) R. Br. on snail hosts of Schistosoma japonicum. Journal of Medicinal Plants Research. 5(4): 521-526.

[123] Wink M, Schmeller T, Latz-Bruning B (1998) Modes of action of allelochemical alkaloids: Interaction with neuroreceptor, DNA and other molecular targets. Journal of Chemical Ecology. 24(11). 1881-1937.

[124] Li Z.H, Wang Q, Ruan X, Pan D, Jiang DA (2010) Phenolics and Plant Allelopathy. Molecules. 15:8933-8952.

[125] Summers CB and Felton GW (1994) Prooxidant effects of phenolic acids on the generalist herbivore Helicoverpa zea (Lepidoptera: Noctuidae): Potential mode of action for phenolic compounds in plant antiherbivore chemistry. Insect Biochemistry and Molecular Biology. 24(9):943-953.

[126] Johnson KS and Felton GW (2001) Plant phenolics as dietary antioxidant for herbivore insects: a test with genetically modified tobacco. Journal of Chemical Ecology. 27(12):2579-2597

[127] Jung M and Park M (2007) Acetylcholinesterase inhibition by flavonoids from Agrimonia pilosa. Molecules. 12: 2130 - 2139.

[128] Kuroyanagi M, Arakawa T, Hirayama Y and Hayashi T (1999) Antibacterial and anti androgen flavonoids from Sophera flavescens. J Nat Prod. 62: 1595 - 1599.

[129] Moore SJ and Lenglet AD (2004) An overview of plants used as insect repellents. In: Traditional medicinal plants and malaria, eds. Wilcox M., Rasoanaivo P., Bodeker G., CRC press, Boca Ratan, FL, USA. 343 - 363. 